\title{
Basement control on dyke distribution in Large Igneous Provinces: case study of the Karoo triple junction
}

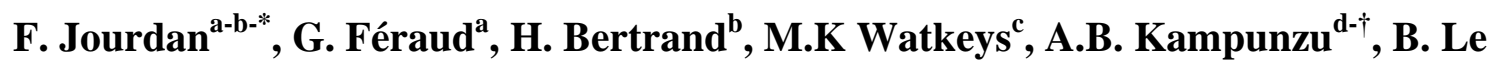 \\ Gall $^{\mathrm{e}}$
}

\begin{abstract}
${ }^{a} U M R-C N R S 6526$ Géosciences Azur, Université de Nice-Sophia Antipolis, O6108 Nice, France

${ }^{b}$ UMR-CNRS 5570, Ecole Normale Supérieure de Lyon et Université Claude Bernard, 69364 Lyon, France

${ }^{c}$ School of Geological and Computer sciences, University of Natal. Republic of South Africa

${ }^{d}$ Department of Geology, University of Botswana, Gaborone, Botswana

${ }^{e} U M R-C N R S$ 6538, Institut Universitaire Européen de la Mer, 29280, Plouzané, France,
\end{abstract}

*Present address: Berkeley Geochronology Center, 2455 Ridge Road, Berkeley, CA 94709, USA

$\uparrow$ Deceased in 2004

\section{$\underline{\text { Abstract }}$}

Continental flood basalts consist of vast quantities of lava, sills and giant dyke swarms that are associated with continental break-up. The commonly radiating geometry of dyke swarms in these provinces is generally interpreted as the result of the stress regime that affected the lithosphere during the initial stage of continental break-up or as the result of plume impact. On the other hand, structures in the basement may also control dyke orientations, though such control has not previously been documented. In order to test the role of pre-dyke structures, we investigated four major putative Karoo-aged dyke swarms that taken together represent a giant radiating dyke swarm (the so-called "triple-junction") ascribed to the Jurassic Karoo continental flood basalt $\left(>3 \times 10^{6} \mathrm{~km}^{2}\right.$; southern Africa). One of the best tests to discriminate between neoformed and inherited dyke orientation is to detect Precambrian dykes in the Jurassic swarms. Accordingly, we efficiently distinguished between Jurassic and Precambrian dykes using abbreviated, low resolution, ${ }^{40} \mathrm{Ar} /{ }^{39} \mathrm{Ar}$ incremental heating schedules.

Save-Limpopo dyke swarm samples $(\mathrm{n}=19)$ yield either apparent Proterozoic $(728-1683$ $\mathrm{Ma})$ or Mesozoic (131-179 Ma) integrated ages; the Olifants River swarm $(n=20)$ includes only Proterozoic (851-1731 Ma) and Archaean (2470-2872 Ma) dykes. The single age obtained on one N-S striking dyke (1464 Ma) suggests that the Lebombo dyke swarm includes Proterozoic dykes in the basement as well. These dates demonstrate the existence of pre-Karoo dykes in these swarms as previously hypothesized without supporting age data. In addition, aeromagnetic and air-photo interpretations indicate that: (1) dyke emplacement was largely controlled by major discontinuities such as the Zimbabwe and Kaapvaal craton boundaries, the orientation of the Limpopo mobile belt, and other pre-dyke structures including shear zones and (2) considering its polygenetic, pre-Mesozoic origin, the Olifants River dyke swarm cannot be considered part of the Karoo magmatic event.

This study, along with previous results obtained on the Okavango dyke swarm, shows that the apparent "triple junction" formed by radiating dyke swarms is not a Jurassic structure; 
rather, it reflects weakened lithospheric pathways that have controlled dyke orientations over hundreds of millions of years. One consequence is that the "triple-junction" geometry can no longer be unambiguously used as a mantle plume marker as previously proposed, although it does not preclude the possible existence of a mantle plume. More generally, we suggest that most Phanerozoic dyke swarms (including triple junctions) related to continental flood basalts were probably controlled in part by pre-existing lithospheric discontinuities.

Keywords: ${ }^{40} \mathrm{Ar} /{ }^{39} \mathrm{Ar}$ dating; dyke swarm; triple junction; Karoo; mantle plume; basement control; structural inheritance

\section{Introduction}

Continental flood basalts (CFB) are the result of huge magmatic events that are particularly abundant during the Phanerozoic (see a review in [1]). Most of them are linked to the Pangea mega-continent fragmentation (e.g. Central Atlantic, Parana-Etendeka, Deccan), and are characterized by the occurrence of giant dyke swarms emplaced in a radial pattern (e.g. [2]). Dyke swarms are significant in part because their geometries are generally considered to be paleo-stress and -strain markers and as such they are useful for recognizing mantle plume impact sites [3].

However, dyke swarms are also known as plate discontinuity markers ([4]) and more recent investigations support the preponderant role played by the pre-existing structure of the lithosphere in controlling dyke-swarm emplacement $[5,6,7]$ and/or CFB-related rift settings $[8,9]$. Consequently, the dyke distributions may not reflect a "primary" structural signature but would highlight preexisting lithospheric weaknesses. Nevertheless, few studies have focused on this issue, and the possible influence of various basement structures (e.g. edges of the craton, mobile belts, shear zones, older dyke swarms) on CFB emplacement is still poorly constrained.

The Karoo CFB formed during a $\sim 180$ Ma magmatic event occurring prior to the southern Gondwana break-up and the opening of the Indian Ocean. It consists of tholeiitic lava-flows, sills and dykes covering a paleo-surface in excess of $3 \times 10^{6} \mathrm{~km}^{2}[10]$. Huge dyke swarms (the N110 ${ }^{\circ}$-striking Okavango, the N70 ${ }^{\circ}$-striking Save-Limpopo, the knee-shaped Olifants River and the N-S Lebombo dyke swarms; Fig. 1; e.g. [11]) appear to converge at the eastern edge of the province defining a four-branch structure (the so-called "triple-junction"; Fig.1). Although the Karoo "triple junction" has been regarded as a Jurassic, CFB-related structure and a classical example of a mantle plume impact site marker (e.g. [3,12]), it appears that (1) prior to the present work the ages of the dyke swarms were poorly constrained, and (2) the field and petrographic evidence contained in published geological maps suggests that some of these dykes are pre-Karoo [13]. Additionally, a recent study demonstrates that the N110 striking branch (i.e. Okavango swarm) includes approximately 12\% Proterozoic dykes and thus is not a neoformed structure [7]. Therefore the Karoo "triple junction" provides an excellent opportunity to investigate the influence of basement structures during CFB emplacement and also the validity of the widely presumed relation between dyke-defined triple-junctions and mantle plumes.

In this paper, we provide age data on the Save-Limpopo (19 dates), Olifants River (20 dates) and Lebombo ( 1 date) dyke swarms, in order to determine if they include Jurassic dykes, preKaroo dykes or both (i.e. if the branches are a neoformed or inherited structure; see [7]). Radiometric dating is the only way to clearly determine if the dykes belong to the Karoo event, because it is generally impossible to do so with field or petrographic observations. Plagioclase was dated rapidly using the ${ }^{40} \mathrm{Ar} /{ }^{39} \mathrm{Ar}$ technique with relatively few heating steps; nevertheless, we were able to unambiguously distinguish between Jurassic and older dykes. 
Possible basement control on dyke swarm emplacement was also investigated using the southern Africa dyke database [14] and air-photo interpretation. Our results provide new constraints on Karoo CFB geodynamics and question models relating the Karoo radiating dyke swarm to mantle plume-head impact. We suggest that our results may have general application to relations between CFB-related dyke swarms and basement structures.

\section{Geological background}

A general description of the province is given by [10]. The N70 ${ }^{\circ}$-oriented Save-Limpopo dyke swarm is generally poorly exposed and extends over ca. $600 \mathrm{~km}$ (Fig. 1) from southeastern Botswana (Tuli basin) to the north-eastern margin of the Limpopo orogenic belt in eastern Zimbabwe. The swarm consists of a 50-100 km-wide corridor of vertical to subvertical dykes with a mean thickness of $27 \mathrm{~m} \mathrm{[15],} \mathrm{although} \mathrm{the} \mathrm{number} \mathrm{of} \mathrm{dykes} \mathrm{measured}$ $(n=13)$ is low. The dykes crosscut the Archaean to Proterozoic metamorphic Limpopo belt and the Karoo Permo-Jurassic sedimentary sequence and lavas, in both the Tuli basin and the Save-Limpopo monocline. Most of the studied dykes are located within the eastern end of the Tuli basin ( $\mathrm{n}=12$; Fig. 2B; Table 1) near Beitbridge where they intrude the basement. Six dykes were also sampled near the western part of the Tuli basin (Fig. 2A). Plagioclase from two dykes yielded plateau $\left(>70 \%\right.$ of ${ }^{39} \mathrm{Ar}$ released) and mini-plateau (between $50 \%$ and $70 \%$ of ${ }^{39} \mathrm{Ar}$ released) ages of $178.9 \pm 0.8(2 \sigma)($ Bot0020) and $180.4 \pm 0.7 \mathrm{Ma}(\mathrm{Bo} 48)$, respectively [10,16] (Fig. 2A). Two dykes (Z44, Z46) intruding the Karoo Save-Limpopo monocline were sampled farther to the east, near the Mutandahwe area (Fig. 2C).

The sigmoidly shaped Olifants River dyke swarm is up to $200 \mathrm{~km}$ wide [17] and extends from the south-west, where few dykes intrude the Karoo sediments [18], to the north-east, where most (but not all) of the Olifants River dykes stop at the limit between the basement and the Karoo sequence of the Lebombo monocline (formed by Karoo sedimentary, basaltic and rhyolitic sequences); Fig. $1 \& 2 \mathrm{D}$ ). The dyke swarm is composed of three successive segments. From south-west to north-east, the dominant direction of the swarm changes from $\sim \mathrm{N} 45^{\circ}$ to $\sim \mathrm{N} 35^{\circ}$ (in the $\sim 2.7 \mathrm{Ga}$ Transvaal Supergroup) and rotates back to $\sim \mathrm{N} 60^{\circ}$ (in the $\sim 3.5$ Ga granitoid-greenstone terrain; Fig. 1 \& 3). Based on different aeromagnetic signatures, the northern Olifants River swarm segment was divided into two sub-swarms [14], a N68 ${ }^{\circ}$ striking minor segment and the $\mathrm{N} 50^{\circ}$-striking Palabora segment. We have chosen to investigate $\mathrm{a} \sim 10 \mathrm{~km}$ section of dykes $(\mathrm{n}=18$; Table $1 \& 2)$ cropping out along the Letaba River in the northern segment, (ca. $23.5^{\circ} \mathrm{S}$ and $31^{\circ} \mathrm{E}$; Fig 2D). This section comprises not only dykes with a typical Olifants River swarm direction $\left(\sim \mathrm{N} 60^{\circ}, \mathrm{n}=12\right)$ but also includes dykes striking E-W $(n=1), N 130^{\circ}(n=4)$ and N-S $(n=1$; more likely belonging to the Lebombo

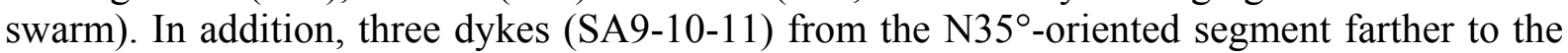
south $\left(26^{\circ} \mathrm{S}\right.$ and $30.5^{\circ} \mathrm{E}$; Fig. 3$)$ were also investigated. SA9 shows a $\mathrm{N} 70^{\circ}$ trend whereas the SA10 and SA1 1 have a N-S orientation.

The Lebombo dykes have a mean orientation of $\sim 175^{\circ} \mathrm{N}$ and mainly intrude the Lebombo monocline (Fig. 1) where they crosscut the whole Karoo basalt sequence. Two plateau ages of $181.4 \pm 0.7$ and $182.3 \pm 1.7 \mathrm{Ma}$ on plagioclase from these dykes were provided by [16]. Scarce N-S oriented dykes also occur in the basement, west of the Lebombo [17]. The three $\mathrm{N}-\mathrm{S}$ oriented dykes are located at about $150 \mathrm{~km}$ (SA10-11) and $30 \mathrm{~km}$ (SA47) from the Lebombo monocline. It is difficult to determine if these dykes belong to the Lebombo or Olifants River dyke swarm.

\section{Petrography}


The investigated Jurassic dykes $(\mathrm{n}=5)$ belong to the Save-Limpopo swarm (Fig 2A \& C) and consist of dolerites containing clinopyroxene and plagioclase with minor amounts of opaque minerals and olivine phenocrysts (except Z46). They are generally fine to medium grained and are relatively fresh with minor evidence of alteration (mainly sericite, serpentine and chlorite). Proterozoic dykes generally display a coarser-grained texture. Proterozoic dykes from west of Tuli ( $n=4$; Fig 2A) show the same paragenesis as Jurassic dykes from which they are hardly distinguishable. On the other hand, Proterozoic dykes from the Save-Limpopo swarm ( $n=14$; Fig. 2B), the Olifants River ( $n=20$; Fig. 2D \& 3) and the Lebombo ( $n=1$; Fig. 2D) swarms differ from the Jurassic dykes by the absence of olivine and the occurrence of significant amounts of amphibole, chlorite, \pm pyrite and interstitial micro-pegmatite. The Proterozoic rocks are more strongly altered compared to Jurassic dykes and plagioclase is more significantly sericitized. Proterozoic dykes are therefore often but not systematically (as illustrated by West Tuli Proterozoic dykes) characterized by amphibole, chlorite and pyrite, as already mentioned for the Okavango swarm [7]. Therefore, petrographic observations may provide potential clues about the age of the dykes but are not sufficient to discriminate conclusively between Proterozoic and Jurassic dykes.

\section{Analytical method}

Most analyses were performed using a relatively fast method so-called "speedy step-heating" [7]. It compromises accuracy but decreases the time spent on each sample relative to ${ }^{40} \mathrm{Ar} /{ }^{39} \mathrm{Ar}$ conventional method. This is appropriate in this study because we aim only to differentiate between Jurassic and Proterozoic dykes. For each sample, five visibly fresh grains (except Bo46 where we used $\sim 10 \mathrm{mg}$ ) were carefully selected using a binocular microscope. The first Ar degassing step (5\% to $37 \%$ of ${ }^{39} \mathrm{Ar}$ released), was performed in order to reduce atmospheric Ar and any Ar from secondary minerals. We measured 3, 6, 4, 5 and 9 additional steps for samples SA11, SA47, SA53, SA55 and SA58, respectively (Fig. 4A \& Table 2). We also performed one more detailed Ar-Ar step heating experiment on the sample Bo46 from the Save-Limpopo swarm (Fig. 4B \& Table 2).

Samples were irradiated for $\sim 70 \mathrm{~h}$ in the Hamilton McMaster University nuclear reactor (Canada) in the position 5c with the Hb3gr amphibole standard (1072 Ma, [19,20]; unpublished analyses performed in Nice and Berkeley; cf. discussion in [7] and [16]). Gas extraction was performed with a $\mathrm{CO}_{2}$ Synrad 48-5 laser and isotopic measurement carried out with a VG3600 mass spectrometer using a Daly-photomultiplier system at the University of Nice. Ages are given at the $2 \sigma$ confidence level. Errors in the age of the monitor are not included in the age calculation. More complete description is given in [7].

It is worth noting that these ages are not meant to be interpreted in detail, as the speedy stepheating method does not allow us to distinguish alteration or excess or loss of argon. Moreover, the appearance of the plagioclase separates and shapes of age spectra suggest that most samples underwent variable perturbations, and so, we report integrated ages for whole samples rather than selected high-temperature steps. Therefore, the ages provided in this study must be used only to differentiate Jurassic and Proterozoic dykes (i.e. Karoo-aged or older) and do not provide precise emplacement ages.

\section{Geochronological results}

Five of nineteen Save-Limpopo dykes yield mostly Jurassic (and one Cretaceous) semiquantitative apparent ages (Fig. 5A) ranging from $131 \pm 2$ to $179 \pm 4 \mathrm{Ma}$ ( $2 \sigma$ error confidence level); the remaining 14 dykes yield substantially older ages ranging from $728 \pm 3$ to $1683 \pm$ 
$18 \mathrm{Ma}$. The sample Bo46 displays a highly disturbed detailed age spectrum (Fig. 4B) with strong evidence of excess argon (as shown by its saddle shape) and alteration, demonstrated by the corresponding variation in ${ }^{37} \mathrm{Ar}_{\mathrm{Ca}}{ }^{39} \mathrm{Ar}_{\mathrm{K}}$ ratio. The Proterozoic ages cannot be attributed to excess Ar affecting the Jurassic dykes as (1) there is no intermediate age between Jurassic and Proterozoic dykes and (2) the dykes mostly show some petrographic differences (e.g. amphibole and pyrite occurrence).

Twenty dykes located in the northern and southern part of the Olifants River dyke swarm display integrated ages ranging from $851 \pm 5$ to $2872 \pm 6 \mathrm{Ma}$ (Fig.5B; Table $1 \& 2$ ). Although these data do not represent geologically significant ages, two relatively distinct populations appear. The first one, ranging from 700 to $1700 \mathrm{Ma}$, displays the same apparent age span as the Proterozoic Okavango dykes and sills (ranging from 850 to $1700 \mathrm{Ma}$; [7]) and the SaveLimpopo dykes. The second population displays older ages between 2.5 and 2.9 Ga showing a noticeable age gap with the first population. No Jurassic age was obtained. More detailed spectra (Fig. 4A) are greatly disturbed showing quasi-systematic mixture of excess Ar (saddle shaped age spectra) and alteration degassing phases (variable ${ }^{37} \mathrm{Ar}_{\mathrm{Ca}}{ }^{39} \mathrm{Ar}_{\mathrm{K}}$ ratio spectra). One $\mathrm{N} 10^{\circ}$ oriented dyke, sampled close to the Lebombo and suspected to belong to the Lebombo dyke swarm yielded a preliminary date at $1264 \pm 7$ Ma (Fig. 2D, Table 1).

\section{Discussion}

\subsection{Geometry of the dyke swarms}

Broad-scale observations show that the so-called "triple junction" is a more complicated structure than portrayed in some oversimplified sketch maps. First, the Okavango and SaveLimpopo dyke swarms, though both of Karoo age ( 179 Ma; $[11,7,16]$ and unpublished data) and referred to as a radiating structure, do not radiate from Mwenezi area, but rather consist of two crosscutting swarms [21,3]; Fig. 1, 6B, 6C) which partially overlap in the Tuli basin area (Fig. 1, 6, 9). Secondly the Olifants River swarm does not converge near Mwenezi but actually stops against the Lebombo monocline hundredth kilometers to the south (Fig. 1, 3, 9). Chavez Gomez [14] provided a summary of mafic dyke swarm orientations in southern Africa produced by digitizing geological and geophysical maps and investigating magnetic data and published literature. This database does not discriminate between Precambrian and Jurassic dykes; nevertheless, it does reveal the effect of basement control on dyke emplacement. The results have been reported in Fig. 1, 3, 6 and 7. Subsequently, we used air photos (focused on our sampling area; cf. Fig. 2B, D) to investigate the distribution and orientation of the four branches at more detailed scale (Fig. 8).

\subsubsection{The Save-Limpopo and Okavango dyke swarms}

Statistical analysis of dyke orientations performed on 1942 dykes from the Save-Limpopo swarm shows a roughly constant direction with a mean strike of $66 \pm 16^{\circ}(1 \sigma$; Fig.6B and 7A) parallel to the Limpopo belt / Zimbabwe craton limit as well as the easternmost (SW-NE oriented) Limpopo structures (Fig. 6A; [22]). On closer inspection, one can observe (1) a subtle rotation of dyke directions from the southwestern $\left(70 \pm 18^{\circ}: \mathrm{n}=900\right)$ part of the swarm, seemingly following (and likely influenced by) the Limpopo belt overall orientation and (2) a difference in direction between the dykes intruding the Limpopo belt and the Zimbabwe craton (Fig. 6C).

The basement intruded by the Okavango swarm $\left(109 \pm 12^{\circ}(n=2320\right.$; Fig. 1$)$ is not well known west of the Tuli basin (mainly due to lack of exposure in the Kalahari Desert) but a recent gravimetric study [23] suggests that the Okavango dykes and the Limpopo mobile belt 
largely overlap (Fig. 1). In its easternmost part (east of $28^{\circ} \mathrm{E}$ ), the Okavango dyke swarm displays a small but noticeable rotation from $110 \pm 12^{\circ}(\mathrm{n}=1656)$ to $\sim 106 \pm 14^{\circ}(\mathrm{n}=604$;

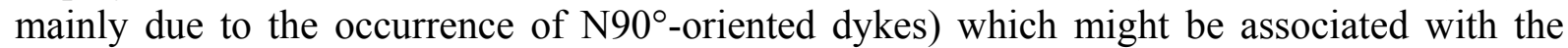
more pronounced rotation (U-shaped) of the Limpopo belt (Fig. 6B). Therefore, the SaveLimpopo and Okavango dyke swarms mimic the U-shape of the Limpopo belt that therefore appears to have influenced the dyke emplacement.

Air photo analysis of a restricted part (see inset in Fig. 2B) of the eastern Tuli basin has been subsequently used to provide a "field-scale" picture of dyke distributions and orientations in this area. The identified and digitized dykes are plotted in rose diagrams (Fig. 8A, B). We split the dykes into two groups; (1) dykes intruding the basement ( $\mathrm{n}=3226$; Fig. 8A), and (2) those intruding the Karoo formation $(\mathrm{n}=945$; Fig. 8B). Both groups show similar dominant directions. In the basement, dykes follow variable orientations but mainly strike between $\mathrm{N} 70^{\circ}$ to $\mathrm{N} 110^{\circ}$. Dykes intruding the Karoo formation are more scarce than those intruding the basement and their orientations are more clustered, with most striking between $\mathrm{N}^{\circ} 5^{\circ}$ and $\mathrm{N} 105^{\circ}$. In both cases, a secondary N-S direction is also apparent (Fig 8B). We interpret this difference as possibly reflecting the strong contribution of the Precambrian dykes in the basement (Fig. 8A). Additionally, the predominant N90 -oriented dykes similarly follow the Limpopo structure (Fig. 6B); these dykes may belong to the Okavango swarm, and may have been influenced by the Limpopo belt structure (see above), or may represent a distinct E-W dyke swarm as illustrated by the presence of a vast quantity of $\mathrm{N} 90^{\circ}$-oriented dykes in the Letaba region (Fig. 8C, D, E).

\subsubsection{The Olifants River dyke swarm}

The Olifants River dykes database [12] includes more than 5000 dykes and shows a wider range of dyke directions than other branches of the radiating structure (Fig. 1, 3 and 7). The dykes strike $45 \pm 21^{\circ}$ in the southern zone, $35 \pm 25^{\circ}$ in the middle zone and $68 \pm 16^{\circ}$ in the northern zone [14]. Uken \& Watkeys [17] have interpreted the northernmost orientation as reflecting (1) a change of the basement nature (Fig. 3) and (2) the existence of multiple dyke generations.

The air photos study is focused on the northern portion of the swarm (Fig. $1 \& 2 \mathrm{D}$ ) in the Letaba region, near the Lebombo. Therefore, the two dyke swarms of Olifants River and Lebombo appear in this area and in the rose diagrams of Fig. $8 \mathrm{C}$ to D. We defined three groups of dykes intruding either basement $(n=913)$, Karoo sandstones of the Clarens formation $(n=87)$, and the Karoo basalts $(n=409)$. In the basement, the dykes display three dominant orientations with a strike of $\sim \mathrm{N} 50^{\circ}$ being most common (Fig. $8 \mathrm{C}$ ). In the Karoo sediments and lavas (Fig. 8D, E), the dyke directions are more variable with an E-W primary direction. The $\mathrm{N} 50^{\circ}$ orientation also exists here as well but is very weakly represented. Airphotos analysis shows that most dykes reported in the basement do not intrude the Jurassic sequence. Therefore, the northern portion of the Olifants River swarm is mainly Precambrian, although a few Jurassic dykes exist.

\subsubsection{The Lebombo dyke swarm}

The Lebombo dykes are mainly distributed along the Lebombo monocline where they crosscut the Karoo basalt sequence (Fig. 1). They show clustered orientations with a mean of $\mathrm{N} 175^{\circ} \pm 17^{\circ}(\mathrm{n}=630)$. In the Karoo basalts and sediments (Fig. 8D, E) the so-called Letaba restricted area shows the N-S dominant direction of dykes related to the Lebombo dyke swarm. Based on study of air photos, (Fig. 8C, D, E), dykes striking N165-180 are present in the basement and probably represent a western extension of the Lebombo dyke swarm. N-S 
dykes also exist within the Limpopo belt (Fig. 8A, B). Therefore, although the Lebombo has probably channeled the main concentration of the N-S dykes, they are more sparsely distributed in the basement to the west (Fig. 8C) and north (Fig. 8A, B) of the Lebombo. We thus suggest that the Lebombo area has possibly constituted a preferential path for magmatic upwelling according to its position at the eastern edge of the Kaapvaal craton. Unfortunately, we cannot evaluate the proportion of Precambrian dykes for this swarm.

\subsection{The Karoo dyke swarms: evidence for inherited orientation}

${ }^{40} \mathrm{Ar} /{ }^{39} \mathrm{Ar}$ "speedy" dating performed on 19 dykes (plus 3 dykes dated in [11] and [16], intruding either basement or Karoo sequences, show that the Save-Limpopo swarm includes both Proterozoic (700-1700 Ma; n=14) and Jurassic dykes (131-180 Ma; n=8; Fig 5a). The youngest apparent age of $131 \mathrm{Ma}$ more likely reflects alteration rather than a Cretaceous emplacement age since the "conventional" ${ }^{40} \mathrm{Ar} /{ }^{39} \mathrm{Ar}$ dates available on the Save-Limpopo dykes reveal a concordant age of $\sim 179 \mathrm{Ma}([11,16]$, unpublished data). Therefore, the Karooaged N70\%/Save-Limpopo swarm shows evidence of structural inheritance from a Proterozoic dyke swarm, along with basement influence marked by discernable rotation of the swarm contiguous to the Limpopo architecture (c.f. discussion above: Fig 6B).

The Olifants River swarm was investigated in its southern and northern regions. The ages obtained seem to indicate two distinct Precambrian dyke events, ranging from 850 to $1700 \mathrm{Ma}$ and from 2500 to $2900 \mathrm{Ma}$. Although the ages obtained are not precise emplacement ages, the apparent ages nevertheless define two populations, consistent with the two different aeromagnetic dyke signatures reported within this portion of the swarm [17,14]. No ages consistent with the Karoo event were obtained, although scarce Karoo dykes are probably present in the Olifants River swarm as shown by a few dykes that crosscut Karoo sediments (see above). Therefore, the Olifants River swarm is likely to include two dominant generations, Archaean and Proterozoic, and possibly a minor component of Jurassic dykes. Thus, the Olifants River dyke swarm can no longer be considered as a Karoo-aged dyke swarm, confirming field observations previously mentioned in [13], and the oldest dykes in the swarm define a weakened pathway that was subsequently followed by two younger generations of dykes.

The last major branch of the Karoo radiating swarm studied is the N-S Lebombo dyke swarm which also includes the Rooi Rand dyke swarm (e.g. [18]). Unfortunately, because the number of outcropping dykes crosscutting the basement is low, it is difficult to test the effect of inheritance in this dyke swarm. Nevertheless, some dykes intrude the basement on the west side of the Lebombo monocline (Fig. 1; see also [18]). This is the case for (1) the SA47 N-S oriented dyke sampled in the Letaba River (Fig. 2D) that yields an apparent age of $1464 \pm 7$ Ma (Table 1), and (2) two N-S dykes sampled in southern extremity of the Olifants River swarm, showing similar Proterozoic ages but for which relations with Lebombo (and Olifants River) swarms are uncertain.

The inheritance demonstrated for the Olifants, Save-Limpopo and possibly the Lebombo dyke swarms is in agreement with similar data obtained on the $\mathrm{N} 110^{\circ}$-oriented Okavango dyke swarm for which the occurrence of a ca. $1 \mathrm{Ga}$ old $\mathrm{N} 110^{\circ}$-oriented dyke swarm clustered in the center of the Jurassic swarm was highlighted [7].

In summary, our results indicate that the Jurassic Save-Limpopo, Lebombo and Okavango dyke swarms parallel Proterozoic dyke swarms, suggesting that dyke emplacement in this region has been repeatedly controlled by features of its ancient basement including craton boundaries and, more subtly, basement belt fabrics. Furthermore, the Olifants River dyke swarm cannot be considered to be dominantly of Karoo age, contrary to previous suggestions [3]. Therefore, the apparent "triple-junction" geometry of these polygenetic dyke swarms 
cannot be used to infer stress patterns at the time of Karoo magmatism. Rather, the apparent triple junction geometry is actually an artifact that is ultimately imposed by the control of preKaroo basement structures on dyke emplacement, as suggested by [13].

\subsection{Implication for the mantle plume hypothesis}

The origin of the Karoo CFB is still matter of debate particularly concerning the possible presence of a mantle plume beneath the province (e.g. [24,25]). In the mantle plume model (as defined for instance by [24,26,27], hot buoyant mantle rises from deep mantle and impinges on the base of the lithosphere. This impact is predicted to trigger (1) crustal doming and (2) the propagation of magma by fracturing crustal to supra-crustal levels from a central point (likely to represent the central axis of the plume; for instance, the Mwenezi-Tuli region for the Karoo case). Based initially on the outcrop pattern of lavas (i.e. no dykes were yet considered), Cox [28] and Burke \& Dewey [29] mentioned the possible link between the Karoo architecture and a mantle plume impact within the Mwenezi area (Fig. 1). Subsequent studies on the Karoo giant dyke swarms have led Ernst et al. [2] and Ernst \& Buchan [3,12] to propose that the Karoo radiating structure (considering the Save-Limpopo, the Olifants River and the Lebombo swarms as the radiating branches) was consistent with a mantle plume impact.

In this study (and in [7]), we show that the "triple junction" structure is probably an artifact characterized by (1) a strong basement control, (2) the occurrence of Precambrian dykes within at least two (and possibly three) branches (Save-Limpopo and Okavango swarms and possibly the Lebombo swarm), (3) a branch (Olifants River) which is not Jurassic in age contrary to previous suppositions (e.g. [3,30]) and (4) a branch (the Save-Limpopo) which does not really radiate from the (Mwenezi area) focal point. Therefore, the apparent radiating structure is not sufficient to infer the existence of a Jurassic mantle plume impact, because Proterozoic dykes, which cannot be related to a plume impact in Karoo time, define a similar pattern (Fig. 9). It is therefore likely that during Jurassic magmatism, basement structures acted to control the orientation of Karoo dykes. Thus, the Karoo dyke swarm geometry should no longer be used to support the Karoo mantle plume hypothesis; nevertheless, a mantle plume origin for Karoo magmatism remains a possibility.

\subsection{The Karoo triple junction and other CFB-related dyke swarms}

CFB and contemporaneous regional dyke swarms generally associated with continental breakup are considered to provide evidence for plume-induced structure ([12] and references therein), but little consideration is generally given to the idea that basement control could constrain dyke swarm (and CFB) geometry. For instance, rifting events apparently take place preferably along pre-existing orogenic fabrics ([9] and references inside). One of the best examples concerns the break-up of Gondwana and the opening of the Atlantic Ocean occurring along the Hercynian, Caledonian and Pan-African belts [9]. Here we provide a brief overview of the relations between selected major dyke swarms associated with the Gondwana break-up (Fig. 10) and their basement structures.

Most dykes located on the circum Central Atlantic continents are related to the $\sim 200 \mathrm{Ma}$ Central Atlantic Magmatic Province (e.g. [31,32,33,34]). Among these dykes, considered to converge towards a focal zone around Florida [35], one of the best defined swarms consists of WNW-ESE dykes in Liberia and their counterpart in French Guyana. The trend of these swarms follows the Pan-African belt separating the West African and Amazonian cratons.

The South Atlantic opening was preceded by intense magmatic activity at $130 \mathrm{Ma}$ forming the Parana-Etendeka CFB associated with several major dyke swarms [36]. Among them, the 
most striking feature is the triple junction formed by the Rio de Janeiro, Florianôpolis and Ponta-Grossa dyke swarms in Brazil [37,38]. The two first branches apparently follow the Pan-African Ribiera and Kaoko belt directions and the third branch follows the Paleozoic Ponta Grossa arch [39]. To the North, the Rio-Cerà-Mirim dyke swarm [40] is also Paranarelated [41] and extends on the northern wedge of the Sao Francisco craton, in a direction parallel to the Pan-African Pernambuco (and its African counterpart) shear zones [42] which may have controlled the swarm orientation. Another Parana-Etendeka related dyke swarm is the $100 \mathrm{~km}$-wide Henties-Bay-Outjo dyke swarm in Namibia [6] which intrudes (and generally follows) the SW-NE oriented Damara mobile belt. Interestingly, the dykes fan out as they leave the Damara belt and intrude the Congo craton at the easternmost extremity of the swarm (Fig. 10) [6].

The gabbroic dyke swarm of the Red Sea rift paralleling the rift structure was emplaced between 24 and $21 \mathrm{Ma}$ [43]. No basement structural control is apparent for the dyke orientations, but this swarm includes both Neogene and Proterozoic dykes (H.B. and G.F., unpublished data), suggesting that the dyking event associated with the Red Sea opening followed an ancient Proterozoic direction.

Finally we mention the radiating dyke swarm (e.g. [2]) related to the $65 \mathrm{Ma}$ [44] Deccan traps in India. One branch of the swarm intrudes and follows the Central Indian Tectonic Zone related to an Early Proterozoic collisional orogen between the southern and northern Indian blocks [45]. The two other branches are parallel to the western limit of the Indian craton.

This brief overview shows that the most prominent dyke swarms related to Gondwana breakup (including those considered to define several triple junctions) mainly follow craton boundaries and are often parallel to mobile belts, shear zones and other pre-existing basement structures (Fig. 10). The dykes were therefore possibly influenced by pre-existing structures with regard to both location and orientation, as we have shown in the Karoo case. Basement control of CFB-related dyke swarms therefore casts doubt on the "active role" of mantle plumes, if any, in causing the "triple junction" pattern marked by the occurrence of radiating dyke swarms. We suggest that a careful re-examination at field scale is required to better constrain the basement influence on giant dyke swarm emplacement.

\section{Conclusions}

Ar/Ar dating and structural analyses were performed on the radiating dyke swarms widely considered to be related to the Karoo igneous province including the Save-Limpopo, the Olifants River and the Lebombo dyke swarms in order to assess controls on their location and orientation. Our data are compared to those recently obtained on the Okavango dyke swarm [6]. We find that:

1. Statistical direction analysis suggests that Karoo dyke orientations are largely controlled by pre-existing structures that also controlled emplacement of Precambrian dykes. The general orientations of the Save-Limpopo $\left(\mathrm{N} 70^{\circ}\right)$ and the Okavango $\left(\mathrm{N} 110^{\circ}\right)$ dyke swarms vary according to the local direction of the Limpopo mobile belt, paralleling craton boundaries. N-S-striking dykes of the Lebombo swarm are rare in the Kaapvaal craton and Limpopo belt, but more abundant at the eastern wedge of the Kaapvaal craton. Varying orientation of the mostly Precambrian Olifants River dyke swarm is systematically associated with changing basement lithology. It is thus suggested that basement structures play a dominant (but not exclusive) role in controlling the orientation of these major dyke swarms.

2. The N45-35-60 $0^{\circ}$ sigmoidly shaped Olifants River dyke swarm is polygenetic and consists mostly of Archaean and Proterozoic dykes though relatively rare Karoo dykes are present. 
Thus, the Olifants River swarm is not dominantly of Karoo age as previously speculated. Moreover, this example highlights that major extensional structures of the southern African lithosphere are often used several times as they constitute favored weakened paths for magmatic injections.

3. Excluding the largely Precambrian Olifants River dyke swarm, two (and possibly three) of the three major Karoo-aged radiating dyke swarms unambiguously include Proterozoic dykes. Therefore, the N70 ${ }^{\circ}$ (Save-Limpopo), the -N110 (Okavango) [7], and possibly the $\mathrm{N}-\mathrm{S}$ (Lebombo) dyke swarms (forming an apparent triple junction) indicate a strong structural inheritance and preclude a neoformed Jurassic radiating structure.

4. The apparent triple junction geometry was not induced by the arrival of a deep mantle plume head but is "inherited" from previous history of the Kaapvaal and Zimbabwe cratons. Therefore, this "triple junction" should no longer be used as an argument for demonstrating (although it does not exclude) the existence of a Karoo mantle plume.

5. Consideration of regional dyke swarms related to other Gondwana CFB shows that they too generally follow pre-existing lithospheric structures such as craton boundaries, mobile belt orientations, basement fabrics and major shear zones. We conclude that the location and orientation of dyke swarms associated with the Gondwana break-up were generally controlled by ancient basement structures and were not "forced" by plume head impact.

\section{Acknowledgments}

We dedicate this paper to the memory of our esteemed colleague A.B. Kampunzu who died in 2004. This work is part of a partnership between the French Universities of Nice, Lyon and Brest and the Universities of Botswana and Kwazulu-Natal (South Africa). We acknowledge the financial support of the CNRS (grant INSU Intérieur de la Terre), the French Ministry of Foreign Affairs, the University of Botswana (Grant RPC Kaapvaal Craton Project R\#442), the SU-CRI 2E of the University of Western Brittany and the Universities of Nice and Lyon. We are grateful to C. Tonani, Head of the Cultural and Scientific Service of the French Embassy in Botswana for his support in developing this program. We thank crews at Kruger National Park. L. Morgan and W. Sharp are acknowledged for English revisions of the manuscript. J.S. Marsh and M. Cosca are thanked for their constructive comments on an earlier version of the manuscript. We thank R.E. Ernst, D. Mège and anonymous reviewer for their thoughtful and very constructive comments. This does not necessarily mean these people agree with the conclusions of this paper. The Editorial handling by K. Farley has been greatly appreciated. Geoscience Azur contribution \# 800.

\section{References}

[1] V.E. Courtillot, P.R. Renne, On the ages of flood basalt events. C. R. Geosciences 335 (2003) 113-140.

[2] R.E. Ernst, J.W. Head, E. Parfitt, E. Grosfils, L. Wilson., Giant radiating dyke swarms on Earth and Venus, Earth Sci. Rev. 39 (1995) 1-58.

[3] R.E. Ernst, K.L Buchan, Giant radiating dyke swarms: their use in identifying preMesozoic large igneous provinces and mantle plumes. In J. Mahoney and M. Coffin (Eds), Large Igneous Provinces: Continental, Oceanic and Planetary Volcanism, AGU Geophysical monograph, vol. 100 (1997) pp. 297-333 
[4] W.F. Fahrig, K.W. Christie, E.H. Chown, D. Janes, N. Machado, The tectonic significance of some basic dyke swarms in the Canadian Superior Province with special reference to the geochemistry and paleomagnetism of the Mistassini swarm, Quebec, Canada Can. J. Earth Sci. 1.23 (1986) 238-253.

[5] D. Mège, T. Korme, Dyke swarm emplacement in the Ethiopian Large Igneous Province: not only a matter of stress, J. Vol. Geotherm. Res. 132 (2004) 283-310

[6] R.B. Trumbull, T. Vietor, K. Hahne, R. Wackerle, P. Ledru, Aeromagnetic mapping and reconnaissance geochemistry of the Early Cretaceous Henties Bay Outjo dike swarm, Etendeka Igneous Province, Namibia, J. Afr. Earth Sci. 40 (2004) 17-29.

[7] F. Jourdan, G. Féraud, H. Bertrand, A.B. Kampunzu, G. Tshoso, B. Le Gall, J.J., Tiercelin, P. Capiez, The Karoo triple junction questioned: evidence from ${ }^{40} \mathrm{Ar} /{ }^{39} \mathrm{Ar}$ Jurassic and Proterozoic ages and geochemistry of the Okavango dyke swarm (Botswana), Earth Planet. Sci. Lett. 222 (2004) 989-1006.

[8] V. Courtillot, C. Jaupart, I. Manighetti, P. Tapponnier, J. Besse. On causal links between flood basalts and continental breakup, Earth Planet. Sci. Lett. 166 (1999) 177-195.

[9] A. Tommasi, A. Vauchez, Continental rifting parallel to ancient collisional belts: an effect of the mechanical anisotropy of the lithospheric mantle, Earth Planet. Sci. Lett. 185 (2001) 199-210.

[10] H.V. Eales, J.S. Marsh, K.G. Cox, The Karoo igneous province: an introduction. In A.J. Erlank (Ed.), Petrogenesis of the volcanic rocks of the Karoo Province, Geological Society Special Publication of South Africa, Vol. 13 (1984) 1-26

[11] B. Le Gall, G. Tshoso, F. Jourdan, G. Féraud, H. Bertrand, J.J. Tiercelin, A.B Kampunzu, M.P. Modisi, M. Dyment, J. Maia, ${ }^{40} \mathrm{Ar} /{ }^{39} \mathrm{Ar}$ geochronology and structural data from the giant Okavango and related mafic dyke swarms, Karoo igneous province, Botswana, Earth Planet. Sci. Lett. 202 (2002) 595-606.

[12] R.E. Ernst, K.L Buchan, Recognizing mantle plumes in the geological record, An. Rev. Earth Planet. Sci. 31 (2003) 469-523.

[13] J.S. Marsh, Discussion "The geophysical mapping of Mesozoic dyke swarms in southern Africa and their origin in the disruption of Gondwana", J. Af. Earth Sciences 35 (2002) 525-527.

[14] S. Chavez Gomez, A catalogue of dykes from aeromagnetic surveys in eastern and southern Africa. ITC publication number 80 (2001).

[15] B. Le Gall, G. Tshoso, J. Dyment, A.B. Kampunzu, F. Jourdan, G. Féraud, H. Bertrand, C. Aubourg, W. Vétel, The Okavango giant mafic dyke swarm (NE Botswana): its structural significance within the Karoo Large Igneous Province, J. Struct. Geol. (in press)

[16] F. Jourdan, G. Féraud, H. Bertrand, A.B. Kampunzu, G. Tshoso, M.K. Watkeys, B. Le Gall., The Karoo large igneous province: Brevity, origin, and relation with mass extinction questioned by new ${ }^{40} \mathrm{Ar} /{ }^{39} \mathrm{Ar}$ age data, Geology 33 (2005) 745-748.

[17] R. Uken, M.K. Watkeys, An interpretation of mafic dyke swarms and their relationship with major mafic magmatic events on the Kaapvaal Craton and Limpopo Belt, South Afr. J. Geol. 100 (1997) 341-348.

[18] M.K. Watkeys, Development of the Lebombo rifted volcanic margin of southeast Africa. In M.A. Menzies, S.L. Klemperer, C.J. Ebinger, J. Bake (Eds), Volcanic rifted margin, Geological Society of America Special Paper, Vol. 362 (2002) pp. 2948.

[19] G. Turner, J.C. Huneke, F.A. Podose, G.J. Wasserbrug, ${ }^{40} \mathrm{Ar} /{ }^{39} \mathrm{Ar}$ ages and cosmic ray exposure ages of Appolo 14 samples, Earth Planet. Sci. Lett. 12 (1971) 19-15. 
[20] P.R. Renne. ${ }^{40} \mathrm{Ar} /{ }^{39} \mathrm{Ar}$ age of plagioclase from Acapulco meteorite and the problem of systematic errors in geochronology. Earth Planet. Sci. Lett. 175 (2000) 13-26.

[21] J.F. Wilson, A craton and its cracks; some of the behaviour of the Zimbabwe Block from the late Archaean to the Mesozoic in response to horizontal movements, and the significance of some of its mafic dyke fracture patterns, J. Afr. Earth Sci. 10 (1990) 483-501.

[22] M.K. Watkeys, Provision geological map of The Limpopo Belt and environs, scale 1/1000000, Geological Society of South Africa, Special publication number 8 (1981).

[23] R.T. Ranganai, A.B. Kampunzu, E.A. Atekwana, B.K. Paya, J.G. King, D.I. Koosimile, E.H. Stettler, Gravity evidence for a larger Limpopo Belt in Southern Africa and geodynamic implications, Geophys. J. International 149 (2002) 9-14.

[24] R.S. White, D. McKenzie, Mantle plumes and flood basalts, J. Geophys. Research 100 (1995) 17,543-17,585.

[25] R.J. Sweeney, A.R., Duncan, A.J. Erlank, Geochemistry and petrogenesis of Central Lebombo basalts from the Karoo Igneous Province. J. Pet. 35 (1994) 95-125.

[26] I.H. Campbell, R.W Griffiths, Implications of mantle plume structure for the evolution of flood basalts. Earth Planet. Sci. Lett. 99 (1990) 79-73.

[27] R.I. Hill, Starting plume and continental break-up. Earth Planet. Sci. Lett. 104 (1991) 398-416.

[28] K.G. Cox, R. Macdonald, G. Hornung, Geochemical and petrographical provinces in the Karoo basalts of southern Africa. Am. Min. 52 (1967) 1451-1474.

[29] K. Burke, J.F. Dewey, Plume generated triple junctions. Key indicators in applying plate tectonics to old rocks, J. Geol. 81 (1973) 403-433.

[30] C. Reeves, The geophysical mapping of Mesozoic dyke swarms in southern Africa and their origin in the disruption of Gondwana, J. Afr. Earth Sci 30 (2000) 499-513.

[31] H. Bertrand, The Mesozoic tholeiitic province of Northwest Africa: a volcanotectonic record of the early opening of Central Atlantic. In A.B. Kampunzu and R.T. Lubala (Eds.) Magmatism in extensional structural settings, Springer Verlag, (1991) pp. 147-188.

[32] A. Sebai, G. Feraud H. Bertrand, J. Hames, ${ }^{40} \mathrm{Ar} /{ }^{39} \mathrm{Ar}$ dating and geochemistry of tholeiitic magmatism related to the early opening of the Central Atlantic Rift, Earth Planet. Sci. Lett. 104 (1991) 455-472.

[33] A. Marzoli, P. Renne, E. Piccirillo, M. Ernesto, G Bellieni, A. De Min, Extensive 200-million-year-old continental flood basalts of the Central Atlantic Magmatic Province, Science 284 (1999) 616-618.

[34] J.G. McHone, Non-plume magmatism and rifting during the opening of the Central North Atlantic Ocean, Tectonophysics 316 (2000) 187-296.

[35] P.R. May, Patterns of Triassic diabase dikes around the north Atlantic in context of predrift position of the continents, Geol. Soc. Am. Bul., 82 (1971) 1285-1292.

[36] D.W. Peate, The Parana-Etendeka Province. In J.J. Mahoney, M.F. Coffin, Large igneous provinces; continental, oceanic, and planetary flood volcanism, AGU Geophysical Monograph Vol. 100 (1997) 217-245

[37] P.R. Renne, K. Deckart, M. Ernesto, G. Féraud, E. Piccirillo, Age of the Ponta Grossa dike swarm (Brazil), and implications to Parana flood volcanism, Earth Planet. Sci. Lett. 144 (1996) 199-211.

[38] K. Deckart, G. Féraud, L.S. Marques and H. Bertrand, New time constraints on dyke swarms related to the Parana-Etendeka magmatic province, and subsequent South Atlantic opening, SE Brazil, J. Volcanol. Geotherm. Res. 80 (1998) 67-83. 
[39] H.K. Chang, R.O. Kowsmann, A.M.F. Figueiredo, A.A. Bender, Tectonics and stratigraphy of the East Brazil Rift System; an overview, Tectonophysics 213 (1992) 97-138.

[40] C.J. Archanjo, R.I Trindade, J.W.P. Macedo, M.G. Araujo, Magnetic fabric of a basaltic dyke swarm associated with Mesozoic rifting in northeastern Brazil, J. S. Am. Earth Sci., 13 (2000) 179-189.

[41] A. Marzoli, P.R. Renne, E.M. Piccirillo, Ar/Ar geochronology of Mesozoic continental basaltic magmatism and the opening of the central, equatorial and southern Atlantic ocean. In: Penrose Conference 2000: Volcanic Rifted Margins. Geology department, Royal Holloway, University of London (2000), pp. 54.

[42] M. Corsini, L. Lambert de Figueiredo, R. Caby, G. Feraud, G. Ruffet, A. Vauchez, Thermal history of the Pan-African/Brasiliano Borborema Province of Northeast Brazil deduced from ${ }^{40} \mathrm{Ar} /{ }^{39} \mathrm{Ar}$ analysis, Tectonophysics 285 (1998) 103-117.

[43] A. Sebai, V. Zumbo, G. Féraud, H. Bertrand, A.G. Hussain, G. Giannérini and R. Campredon, ${ }^{40} \mathrm{Ar} /{ }^{39} \mathrm{Ar}$ dating of alkaline and tholeiitic magmatism of Saudi Arabia related to the early red Sea rifting, Earth Planet. Sci. Lett. 104 (1991) 473-487.

[44] C. Hofmann, G. Féraud, V. Courtillot, ${ }^{40} \mathrm{Ar} /{ }^{39} \mathrm{Ar}$ dating of mineral separates and whole rocks from the Western Ghats lava pile: further constraints on duration and age of the Deccan traps, Earth Planet. Sci. Lett. 180 (2000) 13-27.

[45] G. Zhao, M. Sun, S.A. Wilde, S. Li, A Paleo-Mesoproterozoic supercontinent: assembly, growth and breakup, Earth Sci. Rev. 67 (2004) 91-123.

[46] R.S. Schmitt, R.A. Trouw, J.W.R. Schmus, M.M Pimentel, Late amalgamation in the central part of West Gondwana: new geochronological data and the characterization of a Cambrian collisional orogeny in the Ribeira Belt (SE Brazil), Precambr. Res. 133 (2004) 29-61.

[47] R.H. Steiger, E. Jager, Subcommission on geochronology: convention of the use of decay constants in geo- and cosmochronology, Earth Planet. Sci. Lett. 36 (1977) 359-362.

\section{Figure and table captions}

Figure 1. Location of the Karoo traps and regional dyke swarms; dykes are based mostly on aeromagnetic data and are plotted after the compilation of [14], modified after [7] and references therein). ODS: Okavango; ORDS: Olifants River; SLDS: Save-Limpopo; LDS: Lebombo; SBDS: South Botswana (undated; intruding basement and Karoo group) RRDS: Rooi Rand (undated, intruding Karoo lava-pile); SMDS: South Malawi (undated; intruding basement and Karoo group) and GDS: Gap (undated, intruding Karoo sediments) dyke swarms. Dotted line corresponds to Botswana border. The Kaapvaal and Zimbabwe cratons and Limpopo mobile belt are indicated. Insets A, B, C and D (not to scale) indicate the sampled locations enlarged in Fig. 2. "3" labelled-inset indicates the location of Fig. 3. Inset shows schematic representation of the dyke swarms.

Figure 2. Maps showing locations of dated samples. The rose diagrams indicate the orientations of the dated dykes in each location A) Western Tuli basin; $n=6$. Ar/Ar plateau ages are from [11] and [16] B) Eastern Tuli basin (Beitbridge); n=12. C) Mwenezi basin (Mutandawhe); $n=2$. D) Northern Lebombo (Letaba); $n=17$. Dashed squares correspond to areas delimited by air photos and cited in Fig. 8 with (B) Beitbridge and (D) Letaba. 
Figure 3. Schematic geological map of the northern part of the Olifants River dyke swarm (ORDS; modified from [17] and [14]) with superimposed dykes plotted after the compilation of Chavez Gomez [14]. The three sampled dykes with their apparent ages are indicated. Note the $\mathrm{N} 50^{\circ}$-oriented distinct Palabora dyke swarm (PDS) which seemingly stops before intruding the $2.7 \mathrm{Ga}$ Transvall Supergroup and does not cross cut the $2.1 \mathrm{Ga}$ Palabora complex [17].

Figure 4. Plots showing ${ }^{37} \mathrm{Ar}_{\mathrm{Ca}}{ }^{39} \mathrm{Ar}_{\mathrm{K}}$ ratios and apparent ages for incrementally-heated plagioclases. A) "speedy step-heating" (see text) experiments on selected Olifants River dykes and B) detailed step-heating on sample BO46 (Save-Limpopo swarm). Discordance is interpreted to result from alteration and excess of ${ }^{40} \mathrm{Ar}$.

Figure 5. A, B and C: "Speedy step-heating" ages for (A) the Save-Limpopo (SLDS; black diamond), (B) the Olifants River (ORDS; empty circle) dyke swarm and (C) comparison between the Okavango (ODS, cross) (data from [11] and [7], Save-Limpopo and Olifants River dyke swarm; X axis shows number of analyses. D: Apparent ages of the Letaba dykes vs. their respective orientation; note the cluster (in dashed square) of dykes with Archaean apparent ages and $\sim \mathrm{N} 50^{\circ}$-orientations that were previously attributed to the $\sim 2.7$ Ga (?) Palabora dyke swarm. These dates are low-resolution and should only be used to differentiate among Jurassic, Proterozoic and possibly Archaean dykes.

Figure 6. Sketch map of the Limpopo belt region. A) Structure and tectonic fabric of the Limpopo belt. Major shear zones and sedimentary basins are indicated (after [22]).

Superimposed Okavango (B) and Save-Limpopo (C) dykes after the compilation of [14].

Figure 7. Rose diagram indicating the dyke orientations of the four radiating dyke swarms after [14]. Strike direction is classed by $6^{\circ}$ intervals. (A) Save-Limpopo (SLDS). Number of measurements: 1948 ; largest petal $=375$ values $(19 \%)$; mean orientation $=66 \pm 16^{\circ}(1 \sigma)$. $(\mathrm{B})$ Okavango (ODS). Number of measurements: 2320 ; largest petal $=587$ values $(25 \%)$; mean orientation $=109 \pm 12^{\circ}$. (C) Olifants River (ORDS) and Palabora (PDS). (1) Olifants River. Number of measurements: 4776 ; largest petal $=384$ values $(8 \%)$; mean orientation $=52^{\circ} \pm$ $27^{\circ}$ and (2) Palabora. Number of measurements: 522; largest petal $=159$ values $(30 \%)$; mean orientation $50 \pm 8^{\circ}$. (D) Lebombo (LDS). Number of measurements: 630; largest petal $=109$ values $(17 \%)$; mean orientation $=177 \pm 16^{\circ}$.

Figure 8. Dyke orientations in Beitbridge area (A and B) and Letaba river section $(\mathrm{C}, \mathrm{D}$ and E) (inset Fig. 2) as measured on air-photos. Strike direction is classed by $6^{\circ}$ intervals. Beitbridge: (A) Dykes intruding the basement. Number of measurements: 3226; largest petal $=198$ values $(6 \%)$. (B) Dykes intruding the Karoo formations. Number of measurements: 945; largest petal $=90$ values $(9 \%)$.

Letaba: (C) Dykes intruding basement. Number of measurements: 913; largest petal $=84$ values (9\%). (D) Dykes intruding Karoo sediments (Clarens formation). Number of measurements: 87 ; largest petal $=8$ values $(9 \%)$. (E) Dykes intruding the Lebombo basalts. Number of measurements: 409 ; largest petal $=54$ values $(13 \%)$.

Figure 9. Sketch map of the four radiating dyke swarms based on Ar/Ar ages, aeromagnetic data, and field observations. Plain lines correspond to segments of the swarms in which measurements and observations have been made (this study, $[7,11,16]$ ); dashed lines represent inferred dyke swarm extensions. Densities of dykes within the swarms are not shown. Plots 
show the diachronous intrusion of dykes making up each swarm; dykes intruded prior to the Karoo volcanism (A), and penecontemporaneously with the $\sim 180$ Ma Karoo CFB (B).

Figure 10. Schematic map of part of the Gondwana continent before drifting (modified after [46]) with superimposed CFB-related Phanerozoic dyke swarms of various ages (see text for references; the full extent of CFB are not represented). Cratonic Proterozoic blocks as well as Pan-African / Braziliano, and Paleo-Proterozoic Limpopo and Central Indian [43] mobile belts are shown.

Table 1. Geographic position (GPS spheroid: WGS-84), trend and ${ }^{40} \mathrm{Ar} /{ }^{39} \mathrm{Ar}$ "speedy stepheating" ages of the Olifants River, Save-Limpopo and Lebombo dyke swarms. Both integrated and high temperature ages (excluding pre-degassing step) are given. Analytical uncertainties are $2 \sigma$.

Table 2. ${ }^{40} \mathrm{Ar} /{ }^{39} \mathrm{Ar}$ analytical data for plagioclase from Olifants, Lebombo and Save-Limpopo dyke samples. ${ }^{40} \mathrm{Ar} *=$ radiogenic $\mathrm{Ar} ;{ }^{37} \mathrm{Ar}$ and ${ }^{39} \mathrm{Ar}$ produced by neutron interference with $\mathrm{Ca}$ and $\mathrm{K}$ respectively. The integrated age is calculated by weighting by the percentage of total ${ }^{39} \mathrm{Ar}$ of each step. Decay constants are from [47]. Correction factors for interfering isotopes were $\left({ }^{39} \mathrm{Ar} /{ }^{37} \mathrm{Ar}\right)_{\mathrm{Ca}}=7.30 \times 10^{-4}( \pm 4 \%),\left({ }^{36} \mathrm{Ar}{ }^{37} \mathrm{Ar}\right)_{\mathrm{Ca}}=2.82 \times 10^{-4}( \pm 1 \%)$ and $\left({ }^{40} \mathrm{Ar} /{ }^{39} \mathrm{Ar}\right)_{\mathrm{K}}=$ $2.97 \times 10^{-2}( \pm 3 \%)$. Analytical uncertainties on ages in this table are $1 \sigma$. 


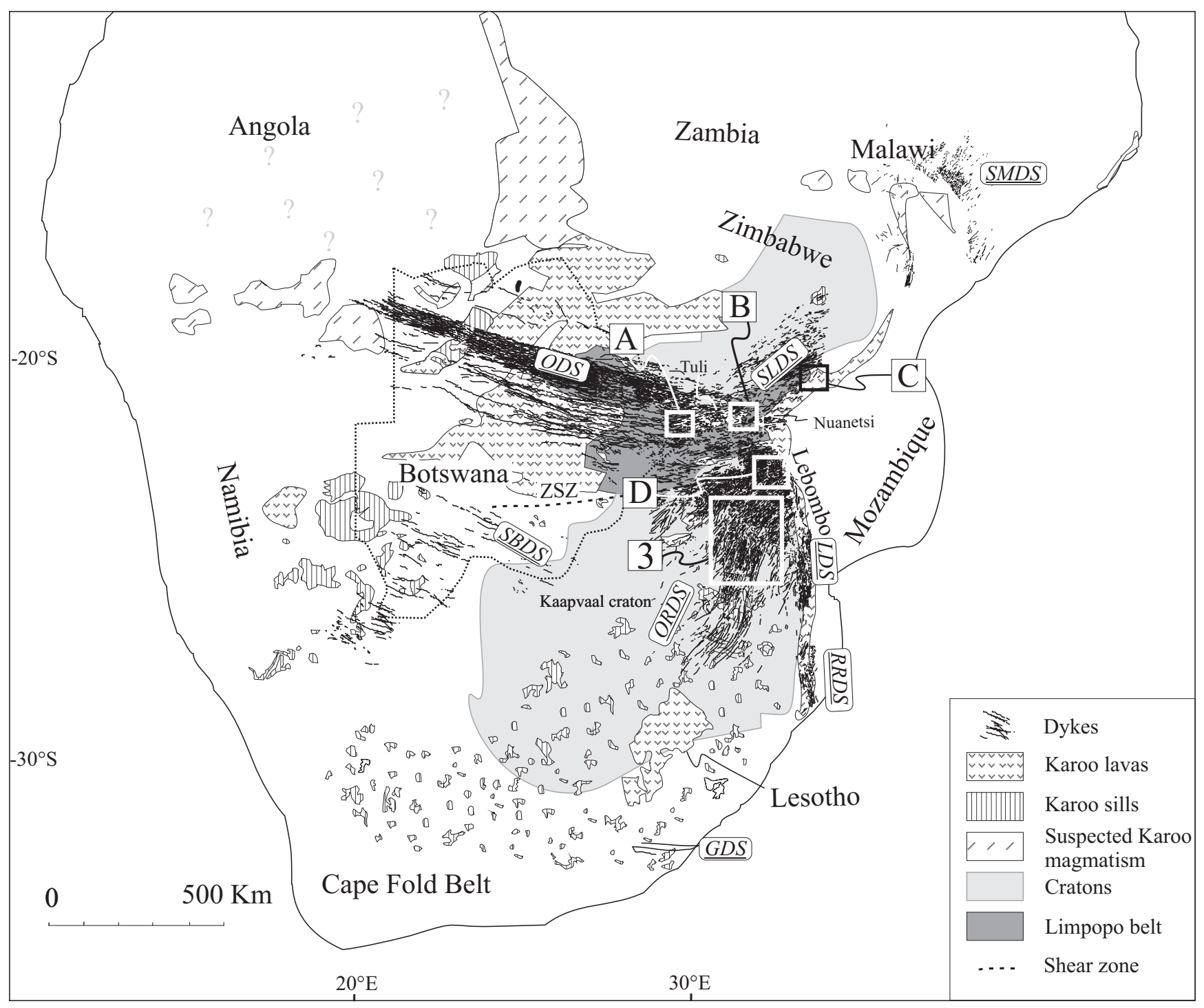

Figure 1: Jourdan et al. 
Figure 2: Jourdan et al.
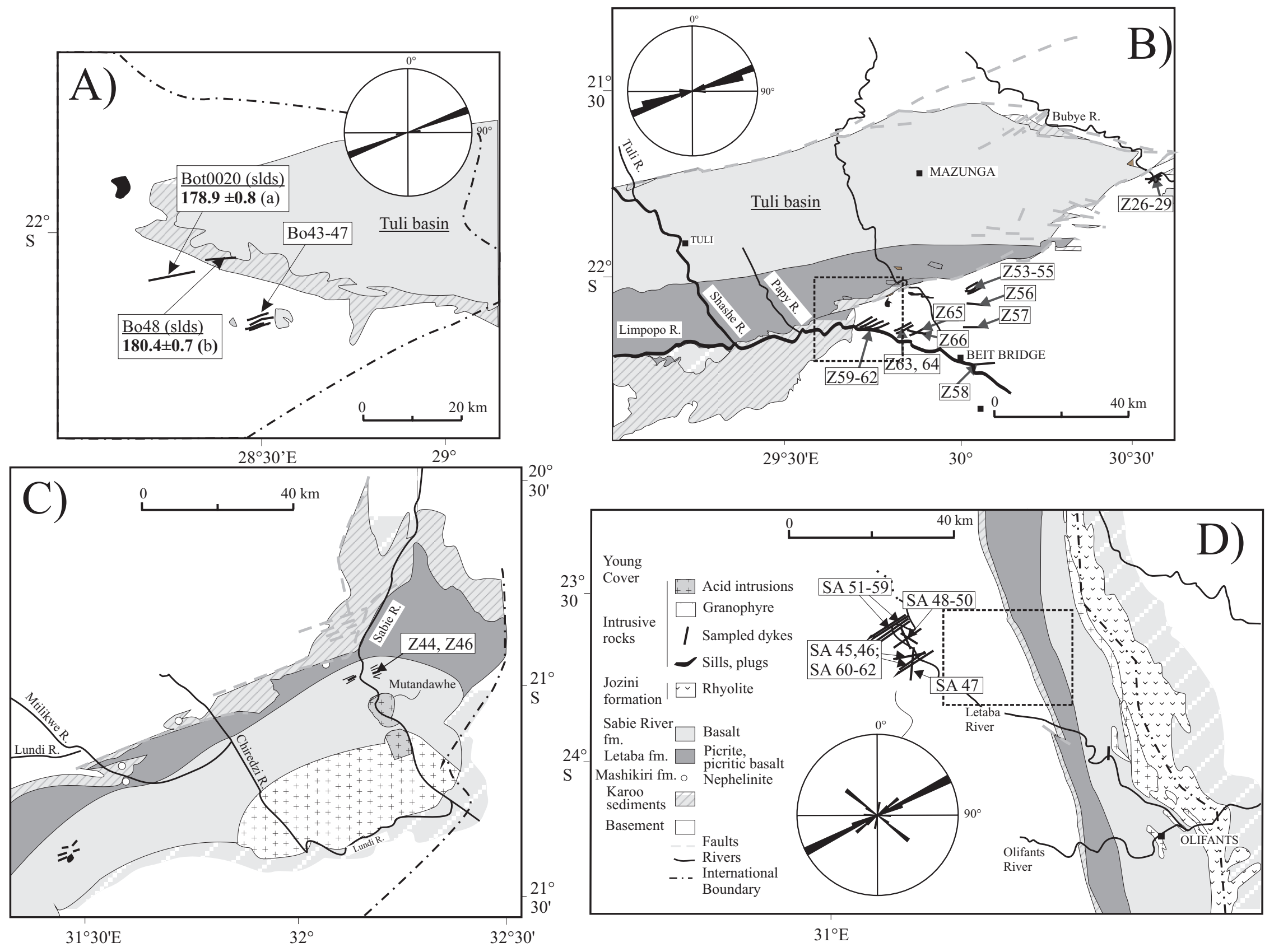


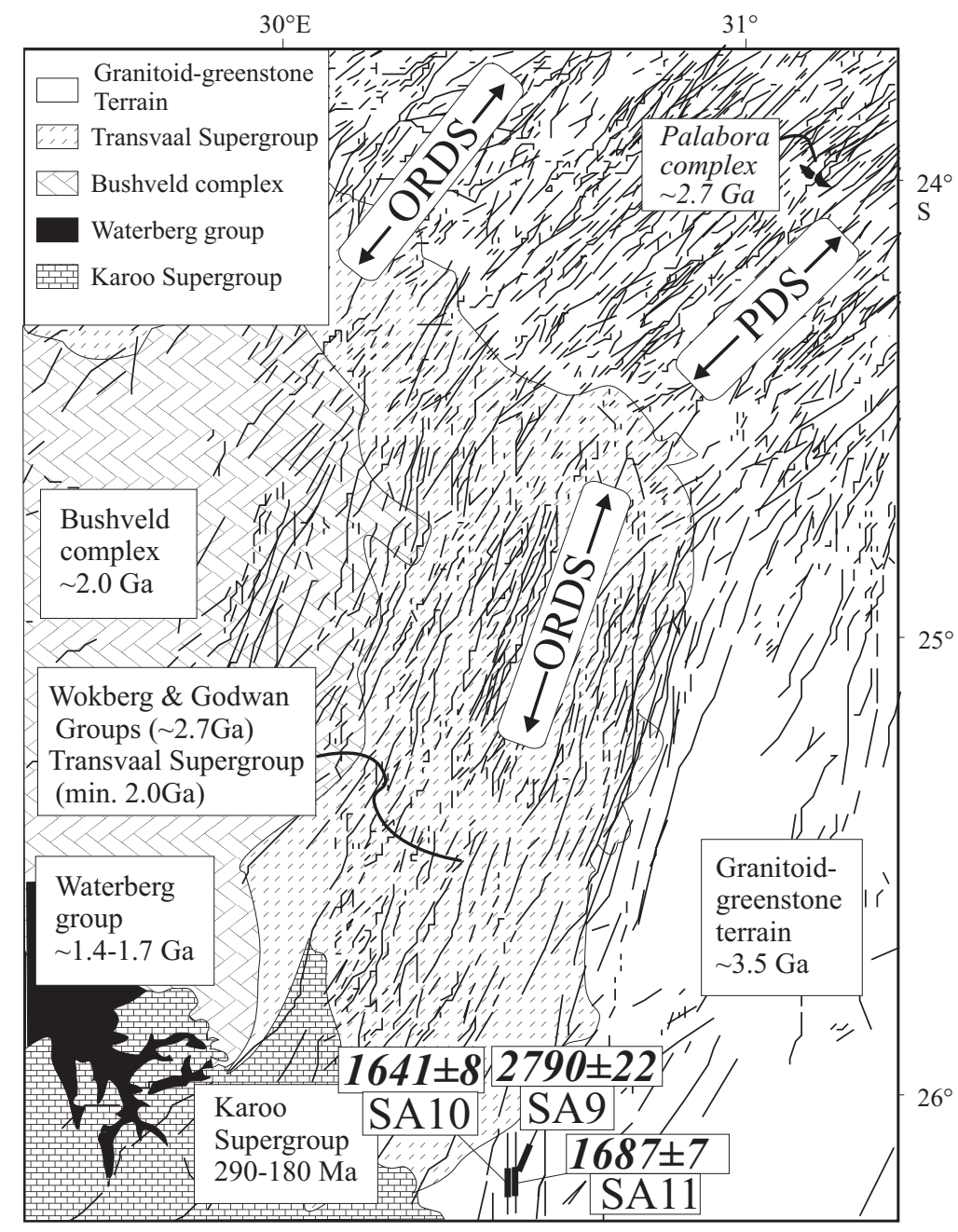

\section{Figure 3: Jourdan et al.}



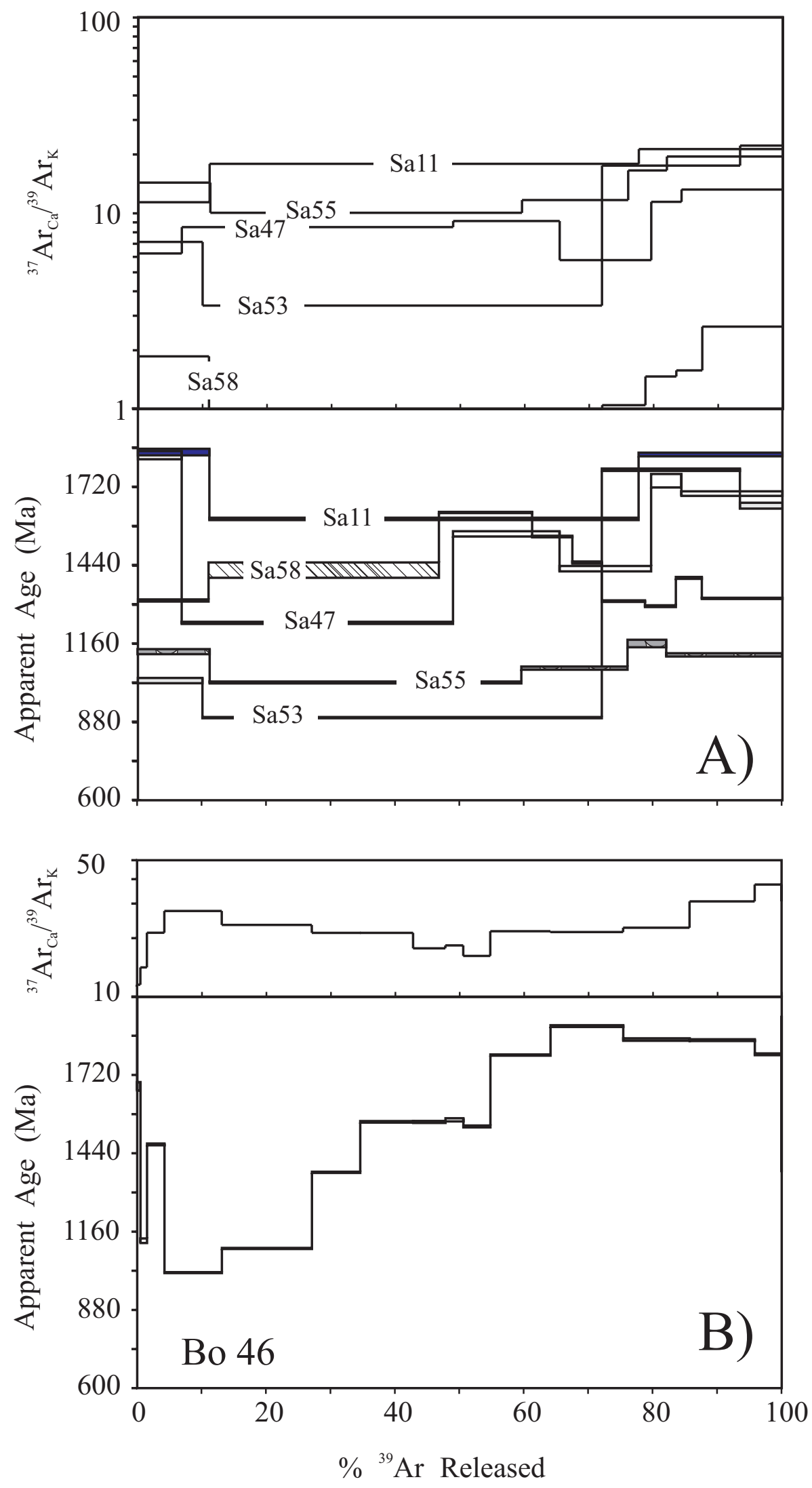

Figure 4: Jourdan et al. 

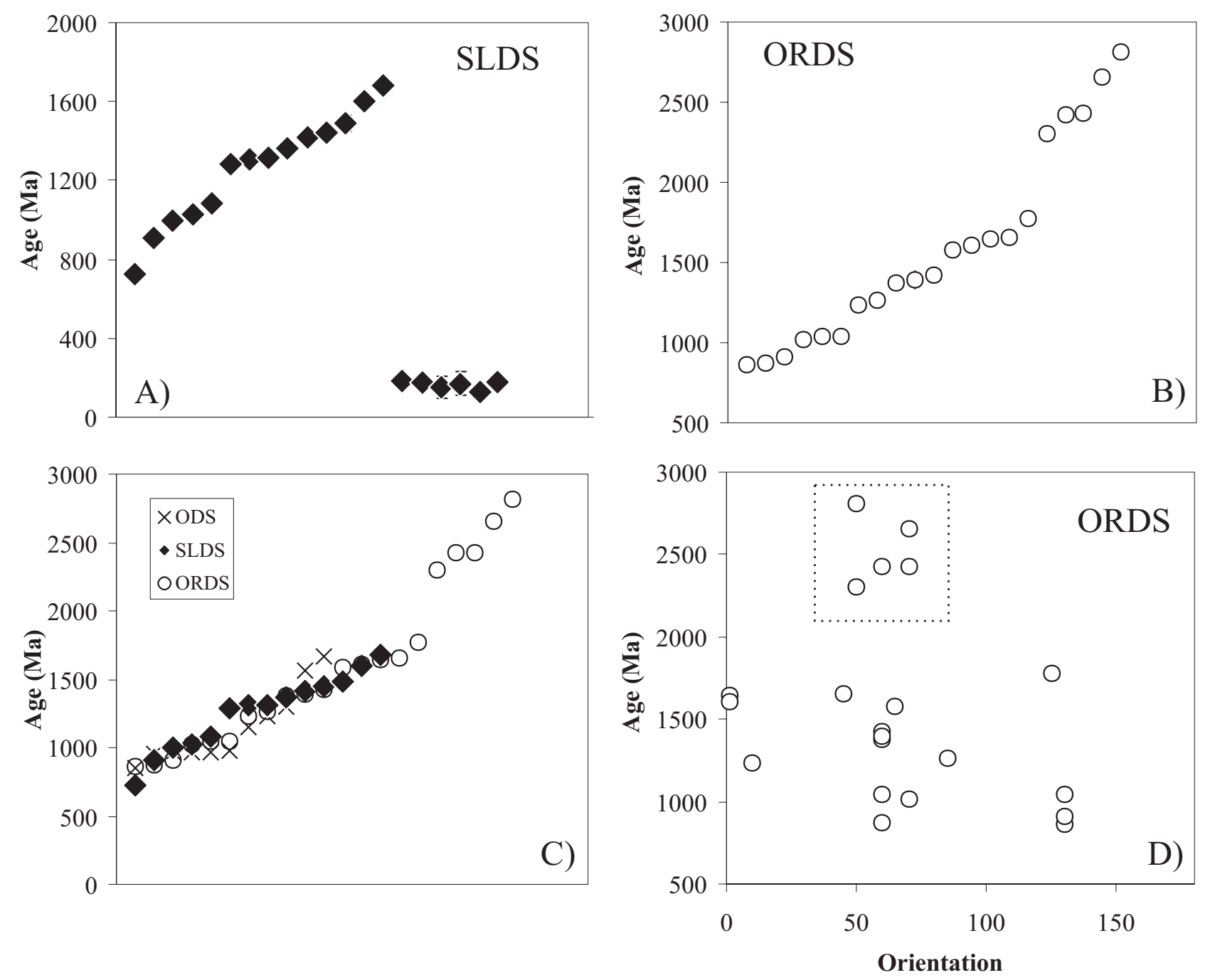

Figure 5: Jourdan et al. 

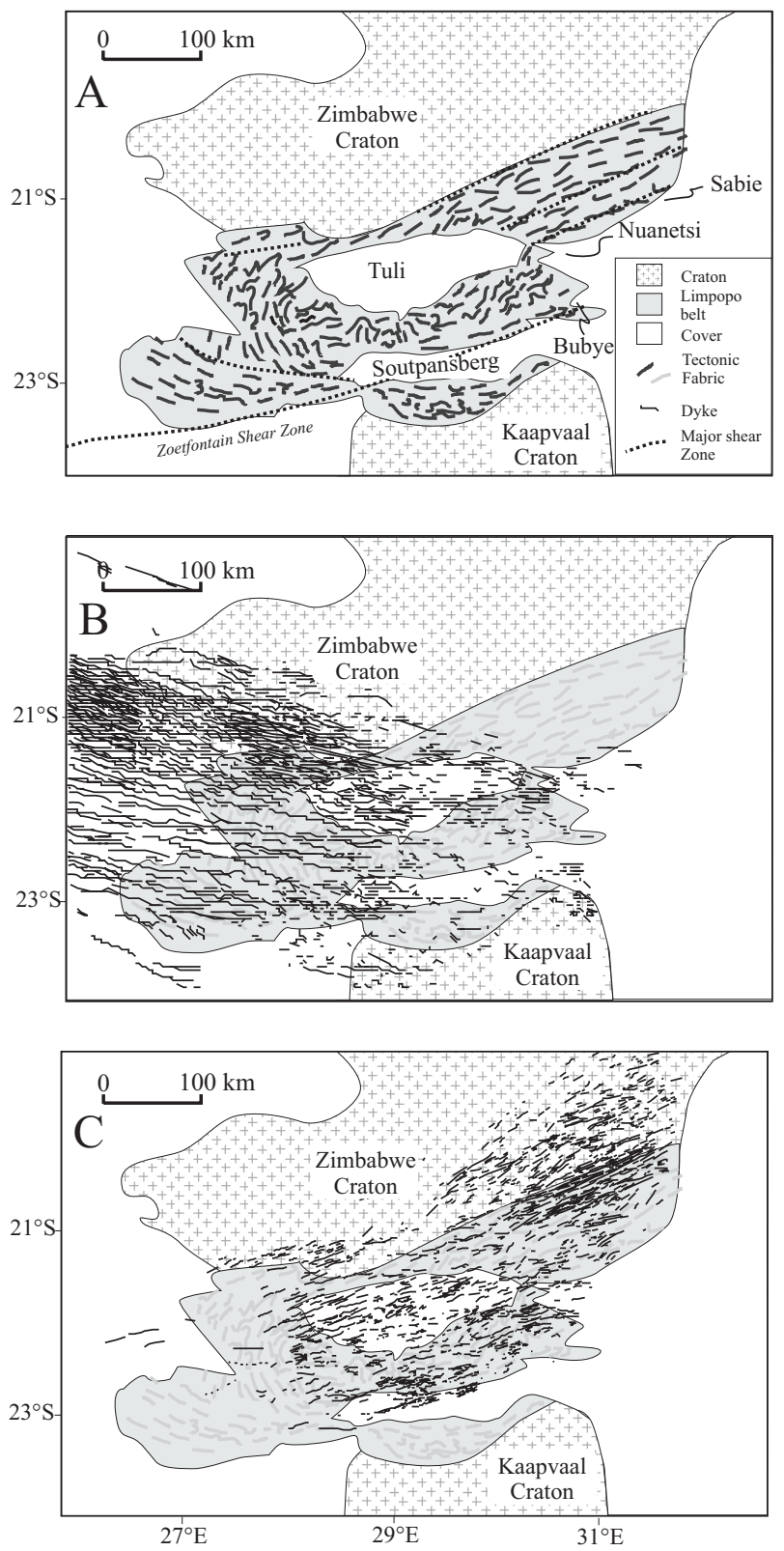

Figure 6: Jourdan et al. 


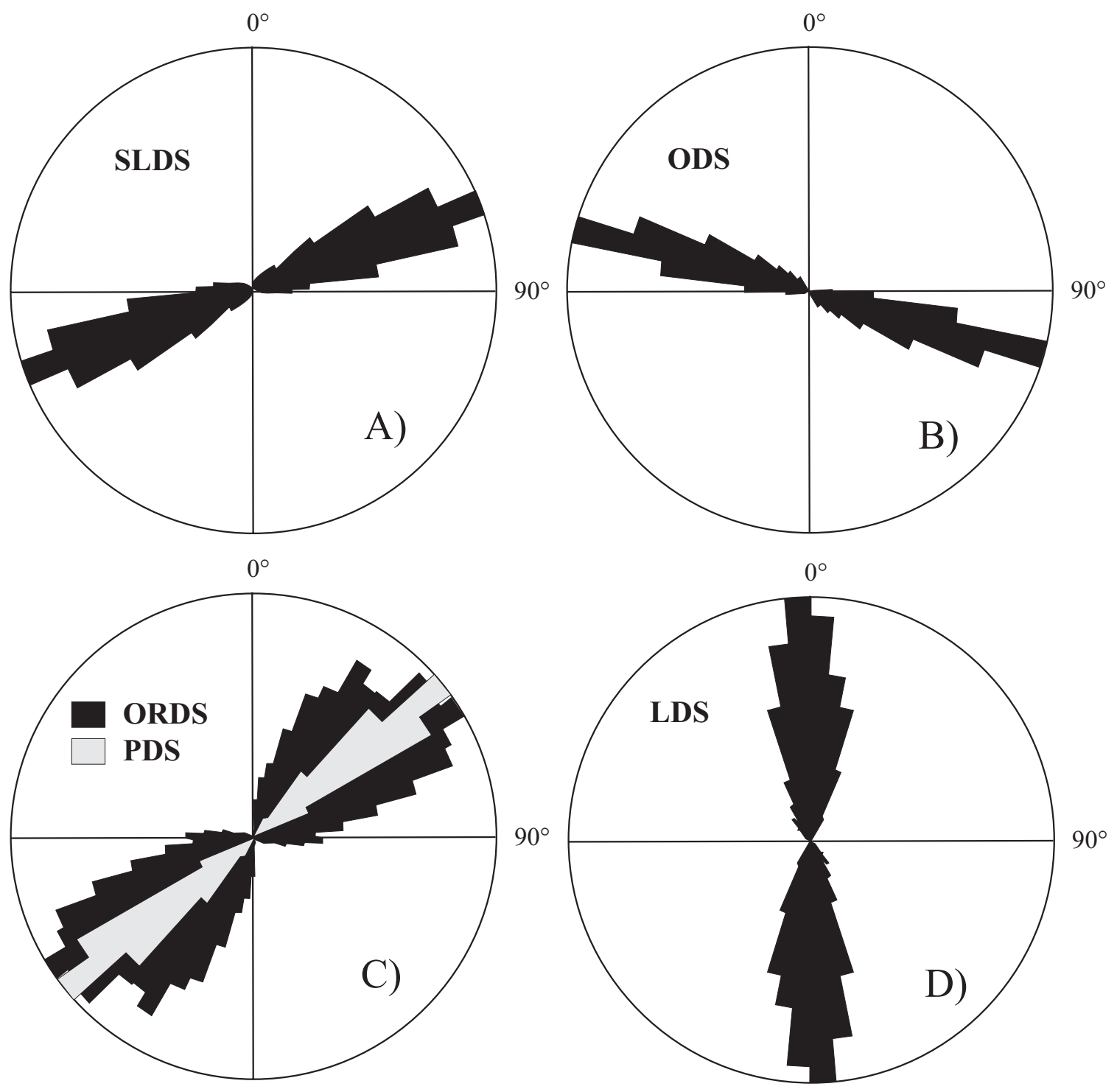

Figure 7: Jourdan et al. 


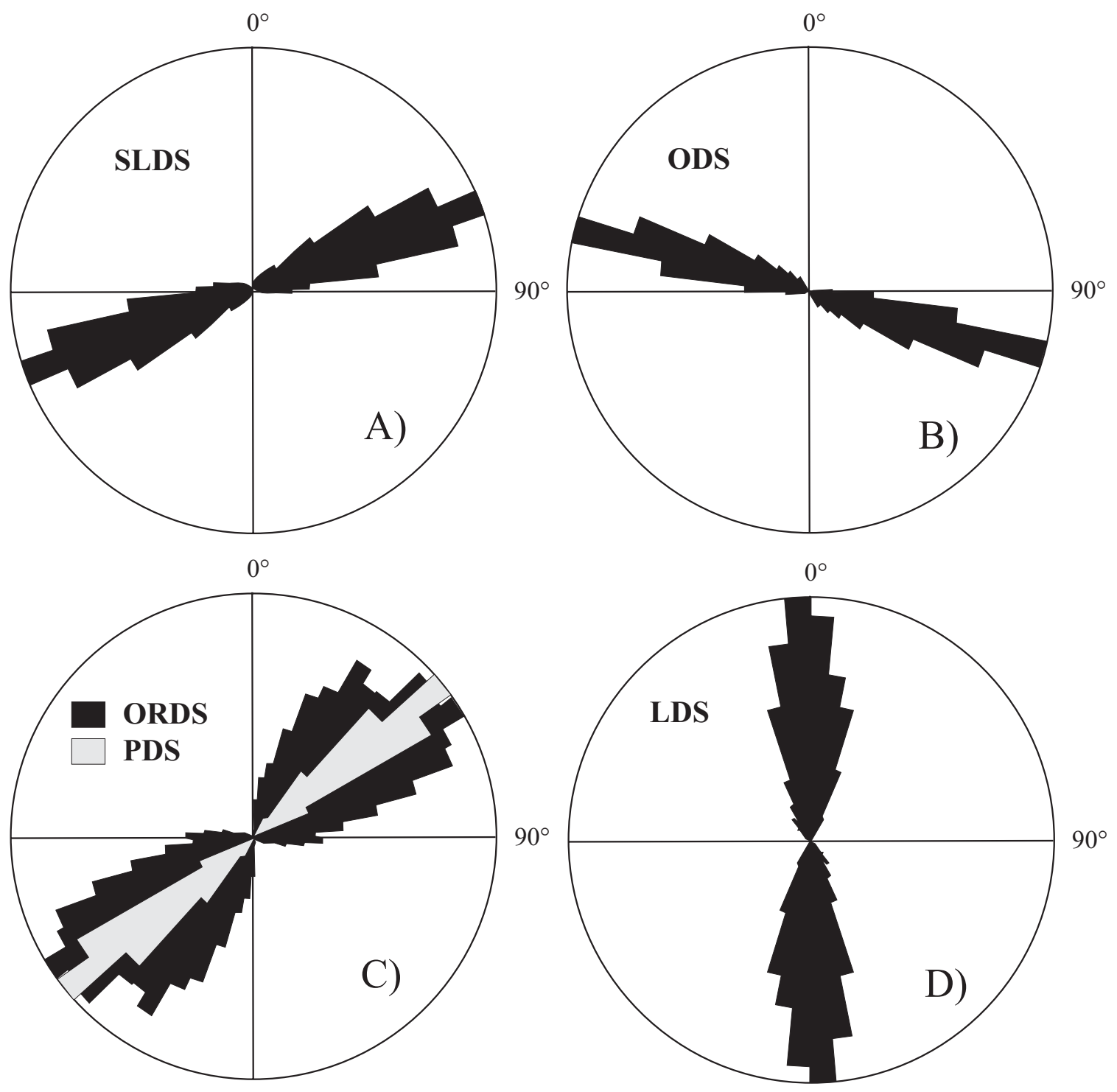

Figure 7: Jourdan et al. 

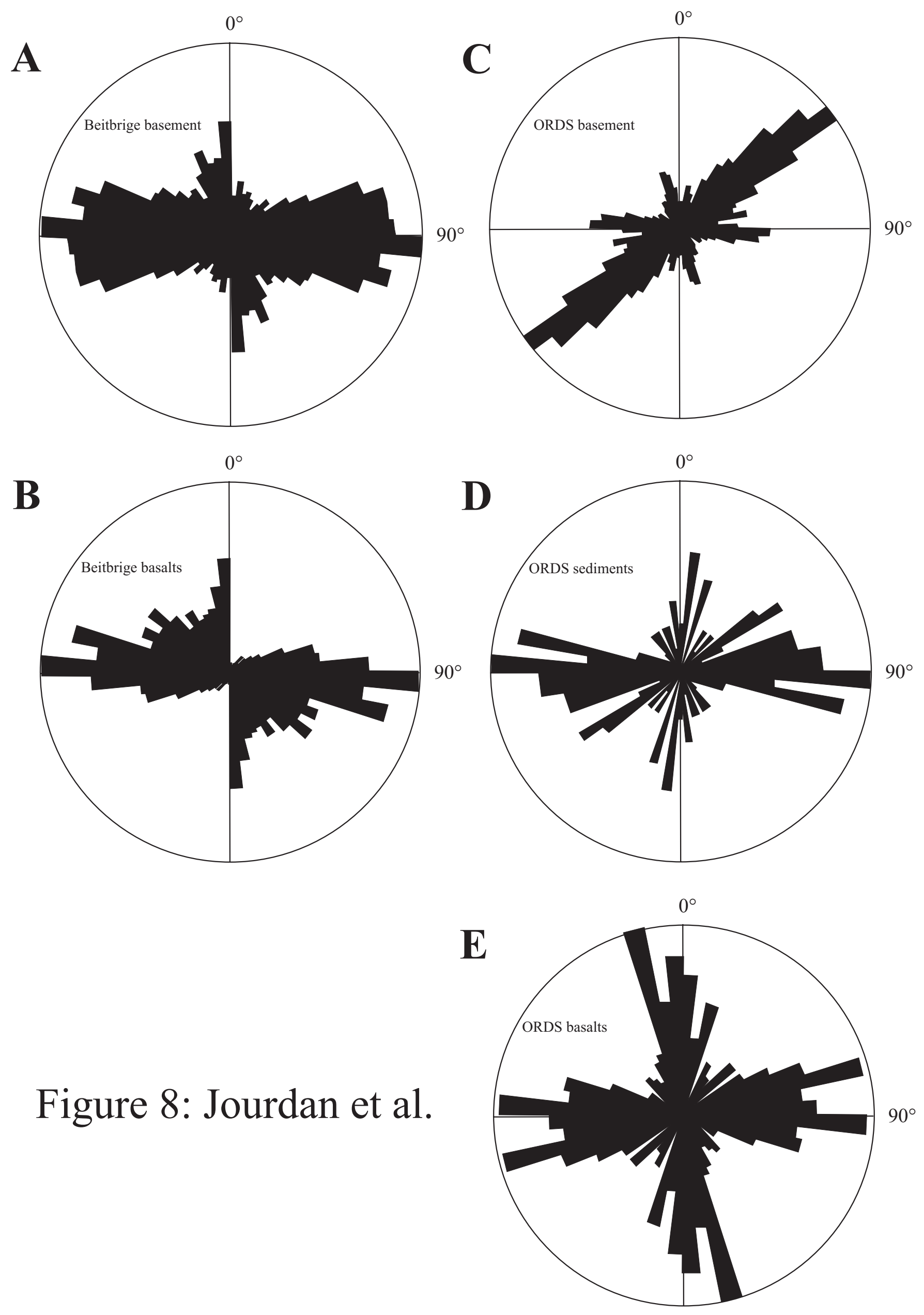

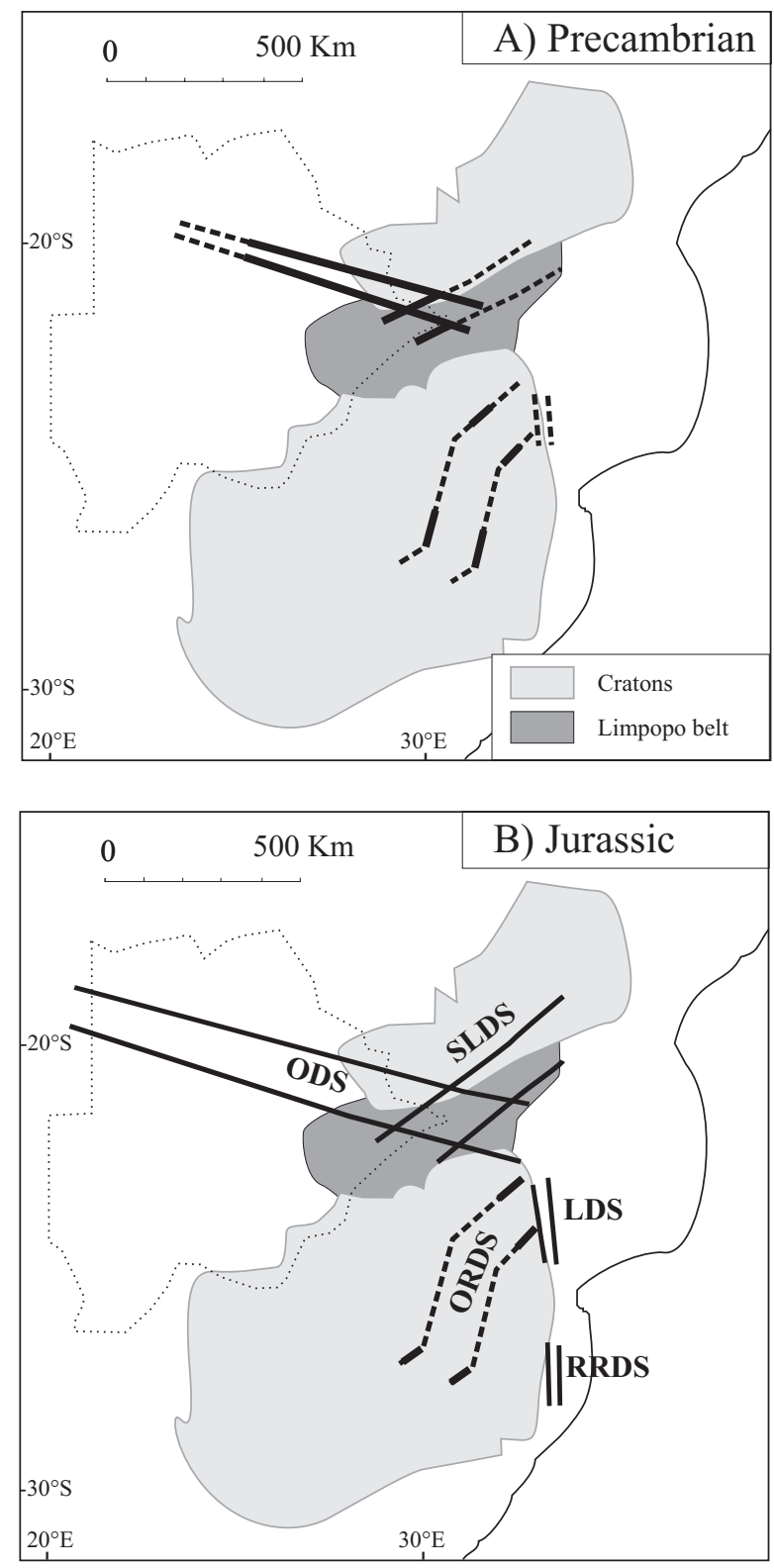

Figure 9: Jourdan et al. 


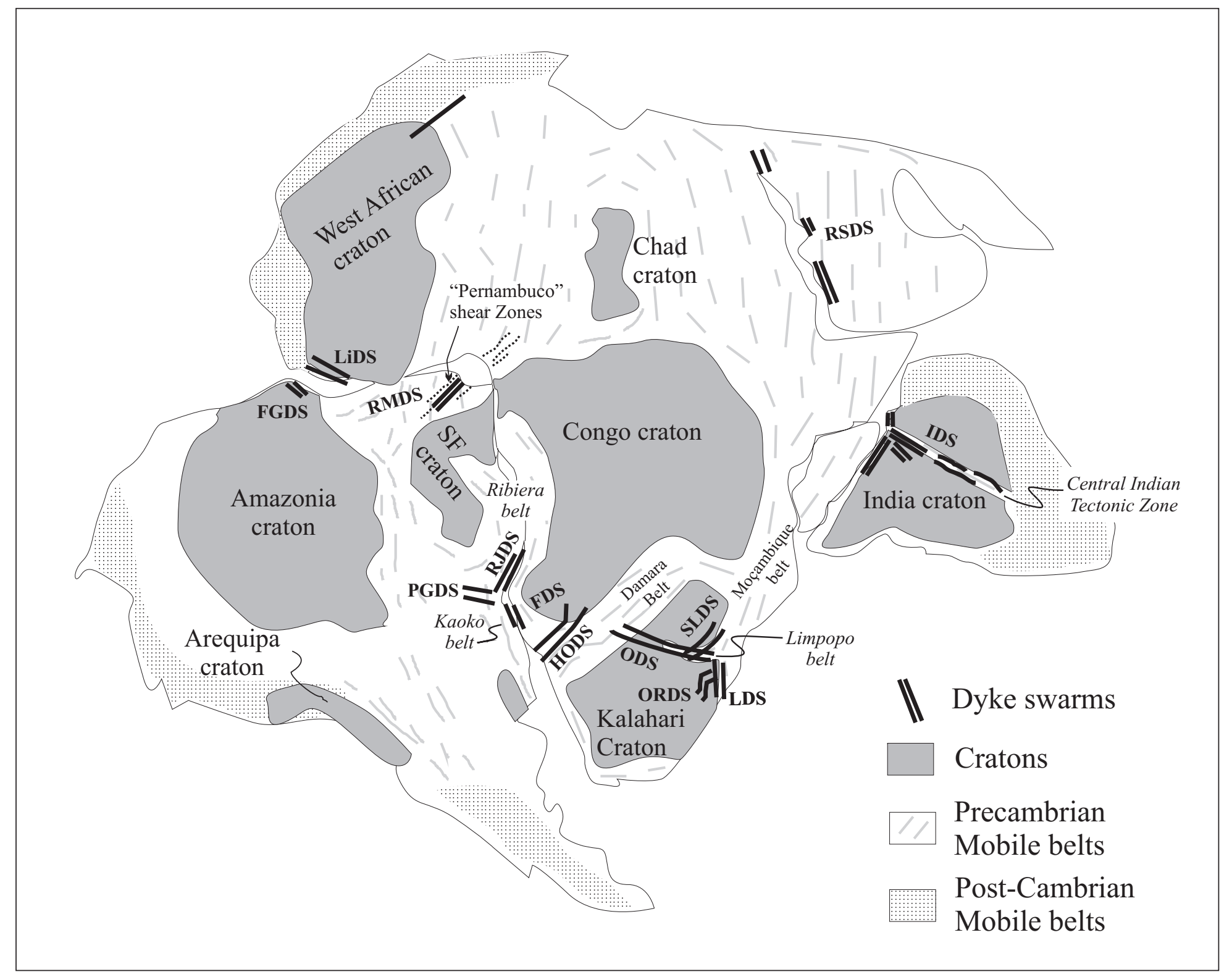

Figure 10: Jourdan et al. 
Table 1

\begin{tabular}{|c|c|c|c|c|c|c|}
\hline SLDS & & & & & & \\
\hline Sample & $\begin{array}{c}\text { GPS } \\
\text { Coordinates }\end{array}$ & Direction & $\begin{array}{l}\text { High temperature } \\
\text { step age } \\
\text { (Ma, } \pm 2 \mathrm{~s})\end{array}$ & step number & $\begin{array}{l}\text { Total 39Ar } \\
\text { released (\%) }\end{array}$ & $\begin{array}{l}\text { Integrated age } \\
\quad(\mathrm{Ma}, \pm 2 \mathrm{~s})\end{array}$ \\
\hline Z29 & $\begin{array}{l}21^{\circ} 43.925^{\prime} \mathrm{S} \\
30^{\circ} 33.805^{\prime} \mathrm{E}\end{array}$ & N60-70 & $925 \pm 5$ & fuse & 94.7 & $1025 \pm 6$ \\
\hline Z28 & $\begin{array}{l}21^{\circ} 43.925^{\prime} \mathrm{S} \\
30^{\circ} 33.805^{\prime} \mathrm{E}\end{array}$ & N70 & - & - & - & $911 \pm 10$ \\
\hline Z66 & $\begin{array}{l}22^{\circ} 07.717^{\prime} \mathrm{S} \\
29^{\circ} 17^{\prime} 90^{\prime \prime} \mathrm{E}\end{array}$ & N70 & $1331 \pm 4$ & fuse & 83.9 & $1306 \pm 4$ \\
\hline Z59 & $\begin{array}{l}22^{\circ} 07.983^{\prime} \mathrm{S} \\
29^{\circ} 41.867^{\prime} \mathrm{E}\end{array}$ & N75 & - & - & - & $1416 \pm 3$ \\
\hline Z54 & $\begin{array}{l}22^{\circ} 01.783^{\prime} \mathrm{S} \\
29^{\circ} 57.200^{\prime} \mathrm{S}\end{array}$ & N70 & $1287 \pm 3$ & fuse & 69.4 & $1284 \pm 3$ \\
\hline Z62 & $\begin{array}{l}22^{\circ} 08.133^{\prime} \mathrm{S} \\
29^{\circ} 43.750^{\prime} \mathrm{E} \text {. }\end{array}$ & N80-85 & $726 \pm 3$ & fuse & 90.9 & $728 \pm 3$ \\
\hline Z64 & $\begin{array}{l}22^{\circ} 07.553^{\prime} \mathrm{S} \\
29^{\circ} 46.225^{\prime} \mathrm{E}\end{array}$ & N75 & $985 \pm 7$ & fuse & 86.6 & $1000 \pm 8$ \\
\hline Z60 & $\begin{array}{l}22^{\circ} 08.083^{\prime} \mathrm{S} \\
29^{\circ} 41.900^{\prime} \mathrm{E}\end{array}$ & N65-75 & $1450 \pm 3$ & fuse & 62.9 & $1445 \pm 3$ \\
\hline Z63 & $\begin{array}{l}22^{\circ} 07.083^{\prime} \mathrm{S} \\
29^{\circ} 45.900^{\prime} \mathrm{E}\end{array}$ & N75 & - & - & - & $1601 \pm 3$ \\
\hline Z61 & $\begin{array}{l}22^{\circ} 07.450^{\prime} \mathrm{S} \\
29^{\circ} 46.950^{\prime} \mathrm{E} \text {. }\end{array}$ & N90 & $1510 \pm 45$ & fuse & 90.5 & $1489 \pm 41$ \\
\hline Bo43 & $\begin{array}{l}22^{\circ} 15.602^{\prime} \mathrm{S} \\
28^{\circ} 35.157^{\prime} \mathrm{E}\end{array}$ & N70 & $1291 \pm 26$ & fuse & 70.6 & $1362 \pm 25$ \\
\hline Bo45 & $\begin{array}{l}22^{\circ} 15.853^{\prime} \mathrm{S} \\
28^{\circ} 34.630^{\prime} \mathrm{E}\end{array}$ & N70 & $1277 \pm 26$ & fuse & 68.9 & $1080 \pm 23$ \\
\hline Bo46 & $\begin{array}{l}22^{\circ} 20.571^{\prime} \mathrm{S} \\
28^{\circ} 16.860^{\prime} \mathrm{E}\end{array}$ & N70 & $1249 \pm 16$ & fuse & 87.3 & $1313 \pm 18$ \\
\hline Bo47 & $\begin{array}{l}22^{\circ} 20.571^{\prime} \mathrm{S} \\
28^{\circ} 16.860^{\prime} \mathrm{E}\end{array}$ & N70 & $1728 \pm 18$ & fuse & 72.5 & $1683 \pm 18$ \\
\hline Bo48 & $\begin{array}{l}22^{\circ} 06.766^{\prime} \mathrm{S} \\
28^{\circ} 24.704^{\prime} \mathrm{E}\end{array}$ & N80 & $179 \pm 3$ & fuse & 90.3 & $179 \pm 4$ \\
\hline Z53 & $\begin{array}{l}22^{\circ} 01.783^{\prime} \mathrm{S} \\
29^{\circ} 57.200^{\prime} \mathrm{E}\end{array}$ & N75 & $170 \pm 3$ & fuse & 81.4 & $174 \pm 3$ \\
\hline Z55 & $\begin{array}{l}22^{\circ} 01.783^{\prime} \mathrm{S} \\
29^{\circ} 57.200^{\prime} \mathrm{E}\end{array}$ & N70 & $138 \pm 56$ & fuse & 86.2 & $153 \pm 54$ \\
\hline Z46 & $\begin{array}{l}20^{\circ} 57.783^{\prime} \mathrm{S} \\
32^{\circ} 09.683^{\prime} \mathrm{E}\end{array}$ & N65-70 & $143 \pm 39$ & fuse & 84.1 & $169 \pm 60$ \\
\hline Z44 & $\begin{array}{l}20^{\circ} 57.783^{\prime} \mathrm{S} \\
32^{\circ} 09.600^{\prime} \mathrm{E}\end{array}$ & N60 & - & - & - & $131 \pm 2$ \\
\hline
\end{tabular}




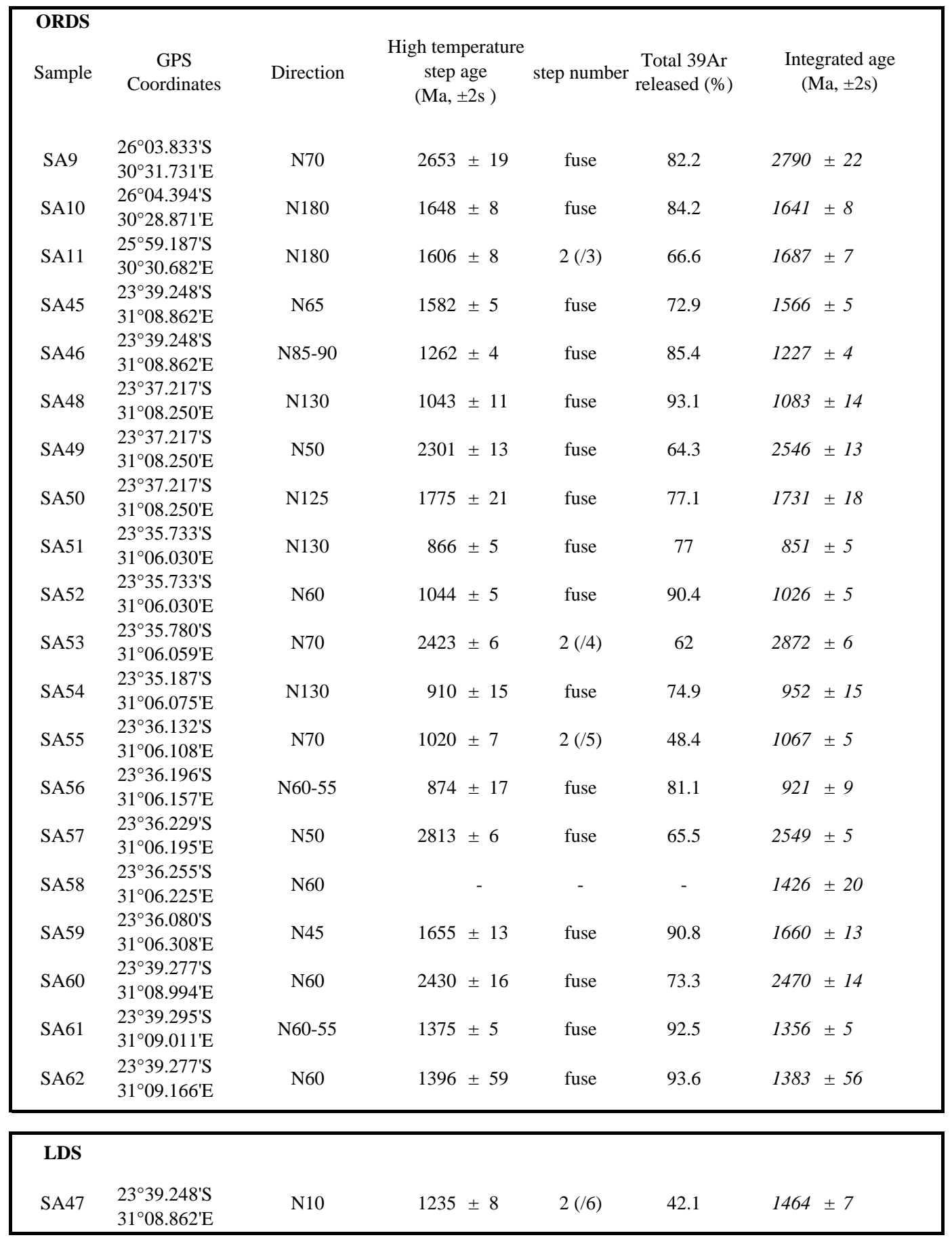




\begin{tabular}{|c|c|c|c|c|c|c|c|c|}
\hline \multirow{3}{*}{ SA9 } & \multirow{3}{*}{$\begin{array}{c}\begin{array}{c}\text { Temperature } \\
\left({ }^{\circ} \mathrm{C}\right) / \text { step }^{\circ}\end{array} \\
1 \\
2\end{array}$} & \multirow{3}{*}{$\begin{array}{c}\text { Atmospheric } \\
\text { contamination (\%) } \\
3.7 \\
1.3\end{array}$} & \multirow{2}{*}{$\begin{array}{c}{ }^{39} \mathrm{Ar}(\%) \\
17.8\end{array}$} & \multirow{2}{*}{$\frac{{ }^{37} \mathrm{Ar}_{\mathrm{Ca}}{ }^{39} \mathrm{Ar}_{\mathrm{K}}}{3.5}$} & \multirow{2}{*}{$\frac{{ }^{40} \mathrm{Ar} *{ }^{39} \mathrm{Ar}}{300.4}$} & \multicolumn{3}{|c|}{ Age (Ma) } \\
\hline & & & & & & 3314.2 & \pm & 35.4 \\
\hline & & & 82.2 & 7.3 & 190.8 & 2653.2 & \pm & 9.6 \\
\hline & & & & & I.A. $=$ & 2789.7 & \pm & 11.2 \\
\hline \multirow[t]{3}{*}{ SA10 } & 1 & 3.6 & 15.8 & 6.2 & $\begin{array}{l}81.4 \\
\end{array}$ & 1601.8 & \pm & 11.6 \\
\hline & 2 & 1.1 & 84.2 & 11.2 & 85.0 & 1648.3 & \pm & 4.2 \\
\hline & & & & & I.A. $=$ & 1640.7 & \pm & 4.0 \\
\hline \multirow[t]{4}{*}{ SA11 } & 1 & 1.6 & 11.1 & 11.4 & 101.4 & 1845.2 & \pm & 11.8 \\
\hline & 2 & 1.9 & 66.6 & 17.8 & 81.8 & 1606.6 & \pm & 4.2 \\
\hline & 3 & 0.6 & 22.3 & 21.2 & 100.6 & 1836.6 & \pm & 6.5 \\
\hline & & & & & I.A. $=$ & 1687.1 & \pm & 3.4 \\
\hline \multirow[t]{3}{*}{ SA45 } & 1 & 1.2 & 27.1 & 1.3 & 75.8 & 1523.5 & \pm & 5.0 \\
\hline & 2 & 0.4 & 72.9 & 3.3 & 80.2 & 1581.8 & \pm & 2.7 \\
\hline & & & & & I.A. $=$ & 1566.1 & \pm & 2.4 \\
\hline \multirow[t]{3}{*}{ SA46 } & 1 & 4.7 & 14.5 & 0.4 & 42.7 & 1004.7 & \pm & 7.6 \\
\hline & 2 & 0.1 & 85.5 & 0.5 & 58.0 & 1262.2 & \pm & 2.2 \\
\hline & & & & & I.A. $=$ & 1227.0 & \pm & 2.2 \\
\hline \multirow[t]{7}{*}{ SA47 } & 1 & 7.6 & 6.8 & 6.2 & 100.8 & \begin{tabular}{|l|l}
1834.3 \\
\end{tabular} & \pm & 14.7 \\
\hline & 2 & 1.3 & 42.1 & 8.5 & 56.2 & 1235.0 & \pm & 4.0 \\
\hline & 3 & 1.0 & 16.5 & 9.1 & 78.0 & 1553.0 & \pm & 9.5 \\
\hline & 4 & 0.0 & 14.2 & 5.8 & 69.0 & 1428.5 & \pm & 9.5 \\
\hline & 5 & 1.4 & 4.7 & 11.4 & 93.0 & 1743.1 & \pm & 23.9 \\
\hline & 6 & 0.4 & 15.7 & 13.2 & 89.2 & 1697.2 & \pm & 8.1 \\
\hline & & & & & I.A. $=$ & 1464.3 & \pm & 3.5 \\
\hline \multirow[t]{3}{*}{ SA48 } & 1 & 3.2 & 6.9 & 9.5 & 78.4 & 1555.7 & \pm & 49.8 \\
\hline & 2 & 0.9 & 93.2 & 4.1 & 44.8 & 1042.6 & \pm & 5.6 \\
\hline & & & & & I.A. $=$ & 1082.7 & \pm & 6.8 \\
\hline \multirow[t]{3}{*}{ SA49 } & 1 & 4.3 & 35.7 & 21.4 & 231.0 & 2918.9 & \pm & 11.7 \\
\hline & 2 & 2.2 & 64.3 & 23.7 & 147.5 & 2301.9 & \pm & 6.3 \\
\hline & & & & & I.A. $=$ & 2546.4 & \pm & 6.3 \\
\hline \multirow[t]{3}{*}{ SA50 } & 1 & 6.1 & 22.9 & 14.9 & 80.1 & 1576.0 & \pm & 19.7 \\
\hline & 2 & 1.4 & 77.1 & 18.8 & 96.2 & 1775.9 & \pm & 10.3 \\
\hline & & & & & I.A. $=$ & 1731.4 & \pm & 9.2 \\
\hline \multirow[t]{3}{*}{ SA51 } & 1 & 4.2 & 23.0 & 4.1 & 31.9 & 800.5 & \pm & 7.6 \\
\hline & 2 & 0.7 & 77.0 & 2.9 & 35.2 & 865.6 & \pm & 2.7 \\
\hline & & & & & I. $A .=$ & 850.7 & \pm & 2.7 \\
\hline \multirow[t]{3}{*}{ SA52 } & 1 & 1.5 & 9.6 & 0.2 & 34.0 & 842.0 & \pm & 15.7 \\
\hline & 2 & 0.4 & 90.4 & 0.4 & 44.9 & 1044.1 & \pm & 2.3 \\
\hline & & & & & I.A. $=$ & 1025.7 & \pm & 2.5 \\
\hline \multirow[t]{5}{*}{ SA53 } & 1 & 4.3 & 10.0 & 7.1 & 185.9 & 2612.0 & \pm & 13.5 \\
\hline & 2 & 0.7 & 62.0 & 3.4 & 161.7 & 2423.0 & \pm & 2.9 \\
\hline & 3 & 0.7 & 21.4 & 17.5 & 384.3 & 3688.8 & \pm & 6.3 \\
\hline & 4 & 0.3 & 6.6 & 22.2 & 341.6 & 3505.3 & \pm & 14.8 \\
\hline & & & & & $I . A .=$ & 2872.4 & \pm & 3.1 \\
\hline
\end{tabular}




\begin{tabular}{|c|c|c|c|c|c|c|c|c|}
\hline & $\begin{array}{l}\text { Temperature } \\
\left({ }^{\circ} \mathrm{C}\right) / \text { step n }^{\circ}\end{array}$ & $\begin{array}{c}\text { Atmospheric } \\
\text { contamination (\%) }\end{array}$ & ${ }^{39} \mathrm{Ar}(\%)$ & ${ }^{37} \mathrm{Ar}_{\mathrm{Ca}}{ }^{39} \mathrm{Ar}_{\mathrm{K}}$ & ${ }^{40} \mathrm{Ar} *{ }^{39} \mathrm{Ar}$ & & Mc & \\
\hline \multirow[t]{3}{*}{ SA54 } & 1 & 2.8 & 25.1 & 3.2 & 46.5 & $\begin{array}{l}1071.3 \\
\end{array}$ & \pm & 18.4 \\
\hline & 2 & 0.4 & 74.9 & 7.2 & 37.6 & 910.2 & \pm & 7.5 \\
\hline & & & & & $I . A .=$ & 951.8 & \pm & 7.4 \\
\hline \multirow[t]{6}{*}{ SA55 } & 1 & 5.2 & 11.2 & 14.4 & $\begin{array}{l}49.8 \\
\end{array}$ & 1130.6 & \pm & 8.9 \\
\hline & 2 & 1.3 & 48.4 & 10.1 & 43.4 & 1020.3 & \pm & 3.2 \\
\hline & 3 & 1.2 & 16.5 & 11.7 & 46.4 & 1071.8 & \pm & 5.8 \\
\hline & 4 & 0.0 & 6.0 & 16.6 & 51.5 & 1159.6 & \pm & 13.3 \\
\hline & 5 & 1.1 & 18.0 & 19.6 & 49.1 & 1119.0 & \pm & 5.9 \\
\hline & & & & & I. $A .=$ & 1067.4 & \pm & 2.5 \\
\hline \multirow[t]{3}{*}{$\begin{array}{l}\text { SA56 } \\
\end{array}$} & 1 & 11.6 & 18.9 & 10.5 & 48.8 & 1110.3 & \pm & 24.5 \\
\hline & 2 & 3.7 & 81.1 & 12.4 & 35.8 & 874.8 & \pm & 8.6 \\
\hline & & & & & $I . A .=$ & 921.3 & \pm & 4.3 \\
\hline \multirow[t]{3}{*}{ SA57 } & 1 & 1.5 & 34.5 & 0.8 & 107.2 & 1906.5 & \pm & 4.0 \\
\hline & 2 & 0.4 & 65.5 & 2.4 & 214.6 & 2813.5 & \pm & 3.0 \\
\hline & & & & & I. $A .=$ & 2549.0 & \pm & 2.5 \\
\hline \multirow[t]{10}{*}{ SA58 } & 1 & 3.5 & 11.0 & 1.9 & 61.3 & $\begin{array}{l}1314.8 \\
\end{array}$ & \pm & 3.9 \\
\hline & 2 & 0.0 & 35.8 & 0.8 & 68.6 & 1423.7 & \pm & 27.4 \\
\hline & 3 & 0.2 & 14.5 & 0.5 & 83.9 & 1629.7 & \pm & 2.0 \\
\hline & 4 & 0.3 & 6.2 & 0.7 & 77.3 & 1543.5 & \pm & 2.6 \\
\hline & 5 & 0.7 & 4.6 & 0.9 & 70.5 & 1450.5 & \pm & 3.6 \\
\hline & 6 & 0.8 & 6.7 & 1.0 & 61.1 & 1312.5 & \pm & 2.9 \\
\hline & 7 & 0.8 & 4.8 & 1.5 & 60.0 & 1294.7 & \pm & 3.1 \\
\hline & 8 & 0.9 & 4.0 & 1.6 & 66.7 & 1395.9 & \pm & 3.3 \\
\hline & 9 & 1.3 & 12.5 & 2.6 & 61.8 & 1322.5 & \pm & 2.1 \\
\hline & & & & & I.A. $=$ & 1426.0 & \pm & 9.8 \\
\hline \multirow[t]{3}{*}{$\begin{array}{l}\text { SA59 } \\
\end{array}$} & 1 & 2.8 & 9.2 & 6.8 & 90.4 & 1709.5 & \pm & 30.1 \\
\hline & 2 & 0.7 & 90.8 & 7.6 & 86.0 & 1654.8 & \pm & 6.6 \\
\hline & & & & & I.A. $=$ & 1659.6 & \pm & 6.6 \\
\hline \multirow[t]{3}{*}{ SA60 } & 1 & 1.9 & 26.7 & 7.7 & 181.6 & 2576.5 & \pm & 14.2 \\
\hline & 2 & 0.7 & 73.3 & 10.1 & 162.9 & 2429.7 & \pm & 7.8 \\
\hline & & & & & $I . A .=$ & 2470.1 & \pm & 6.9 \\
\hline \multirow[t]{3}{*}{ SA61 } & 1 & 4.4 & 7.5 & 1.4 & 48.7 & 1111.5 & \pm & 9.2 \\
\hline & 2 & 0.8 & 92.5 & 1.3 & 65.3 & 1374.5 & \pm & 2.3 \\
\hline & & & & & I.A. $=$ & 1356.0 & \pm & 2.3 \\
\hline \multirow[t]{3}{*}{$\begin{array}{l}\text { SA62 } \\
\end{array}$} & 1 & 6.5 & 6.4 & 1.7 & 53.1 & 1185.7 & \pm & 9.7 \\
\hline & 2 & 0.0 & 93.6 & 1.1 & 66.7 & 1396.2 & \pm & 29.4 \\
\hline & & & & & I.A. $=$ & 1383.3 & \pm & 27.8 \\
\hline
\end{tabular}

Table 2 


\begin{tabular}{|c|c|c|c|c|c|c|c|c|}
\hline \multirow[b]{2}{*}{ Bo43 } & \multirow{2}{*}{$\begin{array}{c}\begin{array}{l}\text { Temperature } \\
\left({ }^{\circ} \mathrm{C}\right) / \text { step } n^{\circ}\end{array} \\
1 \\
2\end{array}$} & \multirow{2}{*}{$\begin{array}{c}\text { Atmospheric } \\
\text { contamination } \\
(\%)\end{array}$} & \multirow{2}{*}{$\begin{array}{c}{ }^{39} \mathrm{Ar}(\%) \\
29.4 \\
70.6\end{array}$} & \multirow{2}{*}{$\begin{array}{c}{ }^{37} \mathrm{Ar}_{\mathrm{Ca}}{ }^{39} \mathrm{Ar}_{\mathrm{K}} \\
29.0 \\
28.3\end{array}$} & \multirow{2}{*}{$\begin{array}{c}{ }^{40} \mathrm{Ar} * /{ }^{39} \mathrm{Ar} \\
80.9 \\
63.8 \\
\text { I.A. }=\end{array}$} & \multicolumn{3}{|c|}{ Age $(\mathrm{Ma}, 1 \sigma)$} \\
\hline & & & & & & $\begin{array}{l}1522.7 \\
1291.0 \\
1362.2\end{array}$ & $\begin{array}{l} \pm \\
\pm \\
\pm\end{array}$ & $\begin{array}{l}26.6 \\
13.2 \\
12.4 \\
\end{array}$ \\
\hline Bo45 & $\begin{array}{l}1 \\
2\end{array}$ & $\begin{array}{c}18.9 \\
2.0\end{array}$ & $\begin{array}{l}31.1 \\
68.9\end{array}$ & $\begin{array}{l}12.7 \\
24.8\end{array}$ & $\begin{array}{r}21.6 \\
62.9 \\
\text { I.A. }=\end{array}$ & $\begin{array}{c}546.3 \\
1277.2 \\
1080.1 \\
\end{array}$ & $\begin{array}{l} \pm \\
\pm \\
\pm\end{array}$ & $\begin{array}{l}27.4 \\
12.8 \\
11.7\end{array}$ \\
\hline Bo46 & $\begin{array}{c}550 \\
650 \\
700 \\
750 \\
800 \\
850 \\
900 \\
925 \\
975 \\
1025 \\
1075 \\
1200 \\
1300 \\
1400 \\
1450 \\
1500 \\
1600\end{array}$ & $\begin{array}{c}21.8 \\
38.2 \\
15.1 \\
5.9 \\
2.3 \\
1.1 \\
0.9 \\
0.9 \\
1.0 \\
0.3 \\
1.1 \\
1.1 \\
0.7 \\
1.1 \\
0.8 \\
1.5 \\
33.6\end{array}$ & $\begin{array}{c}- \\
0.5 \\
1.0 \\
2.7 \\
8.9 \\
14.0 \\
7.5 \\
8.2 \\
5.0 \\
2.8 \\
4.2 \\
9.3 \\
11.3 \\
10.3 \\
10.1 \\
4.1 \\
-\end{array}$ & $\begin{array}{c}- \\
11.6 \\
14.2 \\
21.3 \\
27.5 \\
23.4 \\
21.3 \\
21.3 \\
17.7 \\
18.4 \\
16.2 \\
21.7 \\
21.5 \\
22.6 \\
30.8 \\
37.5 \\
-\end{array}$ & $\begin{array}{c}- \\
93.9 \\
53.0 \\
77.0 \\
46.0 \\
51.3 \\
69.6 \\
83.3 \\
83.3 \\
83.9 \\
82.0 \\
103.8 \\
113.5 \\
108.9 \\
108.7 \\
104.0 \\
- \\
\text { I.A. }=\end{array}$ & $\begin{array}{c}- \\
1679.8 \\
1127.7 \\
1472.0 \\
1013.6 \\
1099.9 \\
1372.4 \\
1552.8 \\
1552.4 \\
1560.0 \\
1536.1 \\
1791.4 \\
1895.2 \\
1846.9 \\
1844.7 \\
1794.2 \\
- \\
1579.2\end{array}$ & $\begin{array}{l} \pm \\
\pm \\
\pm \\
\pm \\
\pm \\
\pm \\
\pm \\
\pm \\
\pm \\
\pm \\
\pm \\
\pm \\
\pm \\
\pm \\
\pm \\
\pm \\
\pm \\
\pm\end{array}$ & $\begin{array}{c}- \\
15.0 \\
8.1 \\
3.3 \\
1.7 \\
1.7 \\
2.0 \\
2.7 \\
3.6 \\
5.5 \\
3.3 \\
2.2 \\
3.1 \\
4.4 \\
3.0 \\
3.0 \\
- \\
0.9\end{array}$ \\
\hline Bo47 & $\begin{array}{l}1 \\
2\end{array}$ & $\begin{array}{c}15.3 \\
3.0\end{array}$ & $\begin{array}{l}27.8 \\
72.3\end{array}$ & $\begin{array}{l}28.7 \\
47.1\end{array}$ & $\begin{array}{r}84.0 \\
98.0 \\
\text { I.A. }=\end{array}$ & $\begin{array}{l}1562.0 \\
1727.9 \\
1683.4\end{array}$ & $\begin{array}{l} \pm \\
\pm \\
\pm\end{array}$ & $\begin{array}{c}23.3 \\
8.9 \\
9.0\end{array}$ \\
\hline Bo48 & $\begin{array}{l}1 \\
2\end{array}$ & $\begin{array}{l}9.1 \\
4.1\end{array}$ & $\begin{array}{c}9.7 \\
90.3\end{array}$ & $\begin{array}{l}13.0 \\
13.3\end{array}$ & $\begin{array}{c}6.6 \\
6.4 \\
\text { I.A. }=\end{array}$ & $\begin{array}{l}184.8 \\
178.7 \\
179.3 \\
\end{array}$ & $\begin{array}{l} \pm \\
\pm \\
\pm\end{array}$ & $\begin{array}{c}13.5 \\
1.6 \\
1.7 \\
\end{array}$ \\
\hline $\mathrm{Z} 28$ & 1 & 13.6 & 100.0 & 10.6 & 40.9 & 910.8 & \pm & 9.6 \\
\hline Z29 & $\begin{array}{l}1 \\
2\end{array}$ & $\begin{array}{c}33.1 \\
6.5\end{array}$ & $\begin{array}{c}5.3 \\
94.7\end{array}$ & $\begin{array}{c}14.9 \\
8.9\end{array}$ & $\begin{array}{c}153.3 \\
41.7 \\
\text { I.A. }=\end{array}$ & $\begin{array}{c}2240.9 \\
924.9 \\
1024.7\end{array}$ & $\begin{array}{l} \pm \\
\pm \\
\pm\end{array}$ & $\begin{array}{c}23.0 \\
2.4 \\
3.2\end{array}$ \\
\hline Z46 & $\begin{array}{l}1 \\
2\end{array}$ & $\begin{array}{l}74.3 \\
45.8\end{array}$ & $\begin{array}{l}15.9 \\
84.1\end{array}$ & $\begin{array}{l}42.4 \\
50.0\end{array}$ & $\begin{array}{c}11.2 \\
5.2 \\
\text { I.A. }=\end{array}$ & $\begin{array}{l}297.9 \\
143.2 \\
168.7\end{array}$ & $\begin{array}{l} \pm \\
\pm \\
\pm\end{array}$ & $\begin{array}{c}142.4 \\
19.6 \\
29.9 \\
\end{array}$ \\
\hline Z53 & $\begin{array}{l}1 \\
2\end{array}$ & $\begin{array}{l}37.2 \\
13.2\end{array}$ & $\begin{array}{l}18.7 \\
81.4\end{array}$ & $\begin{array}{c}8.6 \\
11.7\end{array}$ & $\begin{array}{c}6.8 \\
6.2 \\
\text { I.A. }=\end{array}$ & $\begin{array}{l}187.6 \\
170.4 \\
173.6\end{array}$ & $\begin{array}{l} \pm \\
\pm \\
\pm\end{array}$ & $\begin{array}{l}7.1 \\
1.3 \\
1.7\end{array}$ \\
\hline Z54 & $\begin{array}{l}1 \\
2\end{array}$ & $\begin{array}{l}2.0 \\
0.4\end{array}$ & $\begin{array}{l}30.6 \\
69.4\end{array}$ & $\begin{array}{l}1.2 \\
0.6\end{array}$ & $\begin{array}{r}64.3 \\
64.9 \\
\text { I.A. = }\end{array}$ & $\begin{array}{l}1278.1 \\
1286.6 \\
1284.0\end{array}$ & $\begin{array}{l} \pm \\
\pm \\
\pm\end{array}$ & $\begin{array}{l}1.8 \\
1.6 \\
1.3\end{array}$ \\
\hline Z55 & $\begin{array}{l}1 \\
2\end{array}$ & $\begin{array}{l}30.9 \\
32.3\end{array}$ & $\begin{array}{l}13.8 \\
86.2\end{array}$ & $\begin{array}{l}26.1 \\
29.0\end{array}$ & $\begin{array}{c}8.9 \\
5.0 \\
\text { I.A. }=\end{array}$ & $\begin{array}{l}240.0 \\
138.2 \\
152.6\end{array}$ & $\begin{array}{l} \pm \\
\pm \\
\pm\end{array}$ & $\begin{array}{c}136.6 \\
27.9 \\
27.0\end{array}$ \\
\hline Z59 & $\begin{array}{l}1 \\
2\end{array}$ & $\begin{array}{l}1.2 \\
0.2\end{array}$ & $\begin{array}{l}46.7 \\
53.3\end{array}$ & $\begin{array}{l}1.6 \\
1.0\end{array}$ & $\begin{array}{r}70.2 \\
78.2 \\
\text { I.A. }=\end{array}$ & $\begin{array}{r}1358.8 \\
1464.8 \\
1416.0 \\
\end{array}$ & $\begin{array}{l} \pm \\
\pm \\
\pm\end{array}$ & $\begin{array}{l}2.4 \\
1.8 \\
1.5\end{array}$ \\
\hline Z60 & $\begin{array}{l}1 \\
2\end{array}$ & $\begin{array}{l}1.3 \\
0.3\end{array}$ & $\begin{array}{l}37.1 \\
62.9\end{array}$ & $\begin{array}{l}2.8 \\
1.7\end{array}$ & $\begin{array}{r}76.2 \\
77.1 \\
\text { I.A. }= \\
\end{array}$ & $\begin{array}{l}1437.9 \\
1449.7 \\
1445.3 \\
\end{array}$ & $\begin{array}{l} \pm \\
\pm \\
\pm\end{array}$ & $\begin{array}{l}2.6 \\
1.8 \\
1.5 \\
\end{array}$ \\
\hline Z61 & $\begin{array}{l}1 \\
2\end{array}$ & $\begin{array}{l}3.0 \\
2.5\end{array}$ & $\begin{array}{c}9.6 \\
90.5\end{array}$ & $\begin{array}{l}2.2 \\
0.8\end{array}$ & $\begin{array}{r}63.8 \\
81.8 \\
\text { I.A. }=\end{array}$ & $\begin{array}{l}1270.2 \\
1510.0 \\
1488.5\end{array}$ & $\begin{array}{l} \pm \\
\pm \\
\pm\end{array}$ & $\begin{array}{c}3.5 \\
22.3 \\
20.4\end{array}$ \\
\hline Z62 & $\begin{array}{l}1 \\
2\end{array}$ & $\begin{array}{c}11.3 \\
1.8\end{array}$ & $\begin{array}{c}9.1 \\
90.9\end{array}$ & $\begin{array}{l}1.3 \\
0.8\end{array}$ & $\begin{array}{r}32.0 \\
31.0 \\
\text { I.A. }=\end{array}$ & $\begin{array}{l}745.6 \\
725.9 \\
727.7\end{array}$ & $\begin{array}{l} \pm \\
\pm \\
\pm\end{array}$ & $\begin{array}{l}4.8 \\
1.4 \\
1.4\end{array}$ \\
\hline Z63 & $\begin{array}{l}1 \\
2\end{array}$ & $\begin{array}{l}1.3 \\
0.1\end{array}$ & $\begin{array}{l}50.4 \\
49.6\end{array}$ & $\begin{array}{l}1.0 \\
0.5\end{array}$ & $\begin{array}{r}86.4 \\
92.5 \\
\text { I.A. }=\end{array}$ & $\begin{array}{l}1564.6 \\
1637.4 \\
1601.1 \\
\end{array}$ & $\begin{array}{l} \pm \\
\pm \\
\pm\end{array}$ & $\begin{array}{l}2.0 \\
2.1 \\
1.4\end{array}$ \\
\hline Z64 & $\begin{array}{l}1 \\
2\end{array}$ & $\begin{array}{l}4.9 \\
1.9\end{array}$ & $\begin{array}{l}13.4 \\
86.6\end{array}$ & $\begin{array}{c}7.6 \\
13.1\end{array}$ & $\begin{array}{c}52.0 \\
45.4 \\
\text { I.A. }=\end{array}$ & $\begin{array}{c}1091.7 \\
985.0 \\
999.7 \\
\end{array}$ & $\begin{array}{l} \pm \\
\pm \\
\pm\end{array}$ & $\begin{array}{c}19.5 \\
3.3 \\
4.0 \\
\end{array}$ \\
\hline Z66 & $\begin{array}{l}1 \\
2\end{array}$ & $\begin{array}{l}5.3 \\
0.6\end{array}$ & $\begin{array}{l}16.2 \\
83.8\end{array}$ & $\begin{array}{l}4.6 \\
2.4\end{array}$ & $\begin{array}{r}57.2 \\
68.3 \\
\text { I.A. }=\end{array}$ & $\begin{array}{l}1169.7 \\
1330.7 \\
1305.7\end{array}$ & $\begin{array}{l} \pm \\
\pm \\
\pm\end{array}$ & $\begin{array}{l}6.4 \\
1.8 \\
1.9\end{array}$ \\
\hline
\end{tabular}

Table 2 